Published in final edited form as:

J Biomed Sci. 2004 ; 11(3): 278-294.

\title{
Regulation of alternative RNA splicing by exon definition and exon sequences in viral and mammalian gene expression
}

\author{
Zhi-Ming Zheng \\ HIV and AIDS Malignancy Branch, Center for Cancer Research, National Cancer Institute, National \\ Institutes of Health, Bethesda, MD 20892, USA
}

\section{Abstract}

Intron removal from a pre-mRNA by RNA splicing was once thought to be controlled mainly by intron splicing signals. However, viral and other eukaryotic RNA exon sequences have recently been found to regulate RNA splicing, polyadenylation, export, and nonsense-mediated RNA decay in addition to their coding function. Regulation of alternative RNA splicing by exon sequences is largely attributable to the presence of two major cis-acting elements in the regulated exons, the exonic splicing enhancer (ESE) and the suppressor or silencer (ESS). Two types of ESEs have been verified from more than 50 genes or exons: purine-rich ESEs, which are the more common, and non-purinerich ESEs. In contrast, the sequences of ESSs identified in approximately 21 genes or exons are highly diverse and show little similarity to each other. Through interactions with cellular splicing factors, an ESE or ESS determines whether or not a regulated splice site, usually an upstream 3' splice site, will be used for RNA splicing. However, how these elements function precisely in selecting a regulated splice site is only partially understood. The balance between positive and negative regulation of splice site selection likely depends on the cis-element's identity and changes in cellular splicing factors under physiological or pathological conditions.

\section{Keywords}

RNA; exons; introns; alternative RNA splicing; gene expression; RNA processing; splicing enhancers; splicing suppressors

RNA exon sequences were once thought to function simply as coding sequences. Recent advances in RNA research have indicated that the RNA exon sequence has a dual role: protein encoding and RNA processing through interactions with cellular proteins. Recent reviews have described the progress in several aspects of RNA processing research, including messenger RNA-binding proteins [46], network-coupling among gene expression [111], alternative premRNA splicing and proteome expansion [112], exon point mutation and RNA splicing [19], intron elements in alternative splicing [90] and RNA splicing and human diseases [50]. This review will focus on the roles that exon definition and exon sequences play in the regulation of alternative RNA splicing.

\section{Gene expression and RNA splicing}

Most eukaryotic genes consist of exons and introns. Exons are segments of an interrupted gene that are represented in the mRNA, and introns are the sequences that intervene between exons. Each intron has at least three cis-elements: a $5^{\prime}$ splice site ( $\left.5^{\prime} \mathrm{ss}\right)$, a branch site, and a $3^{\prime}$ splice site ( 3 'ss) containing a run of 15 to 40 pyrimidines (usually Us) called a polypyrimidine tract

Zhi-Ming Zheng, M.D., Ph.D., HIV and AIDS Malignancy Branch, Center for Cancer Research, NCI/NIH, 10 Center Dr., Rm. 10 S255, MSC-1868, Bethesda, MD 20892-1868, USA, Tel. 301-594-1382, Fax 301-480-8250, E-Mail: zhengt@exchange.nih.gov. 
(PPT). Most viral and mammalian introns are GU-AG introns, introns that start with a GU dinucleotide at intron $5^{\prime}$ ends and end with an AG dinucleotide at intron $3^{\prime}$ ends, with a few minor AU-AC introns [155;169]. Some exons are noncoding or partially coding exons, which are usually positioned at the 5' or 3' end of an RNA. With few exceptions, the majority of primary RNA transcripts (pre-mRNAs) of viral or mammalian split genes undergo multiple steps of nuclear RNA processing, including RNA 5' capping, RNA splicing, and RNA 3' end polyadenylation, before the mRNA is completely formed and exported to the cytoplasm for protein translation (Fig. 1). Recent studies have demonstrated that nuclear RNA processing is performed by a co-transcriptional network [52;111]. Eukaryotic and viral RNAs transcribed by RNA polymerase II (pol II) have $\mathrm{m}^{7} \mathrm{G}$ caps added to their $5^{\prime}$ ends cotranscriptionally after about 20-30 nucleotides have been synthesized [27;124] recognizing and splicing the first intron on the nascent RNA transcript by cellular splicing machinery along the transcription elongation and emergence of the next exon and intron [53;89;119;172]. This co-transcriptional splicing of the first intron can be greatly enhanced by the RNA capping machinery $[78 ; 101$; 128], but alternative $5^{\prime}$ ss selection in co-transcriptional splicing can be influenced by the transcription rate of RNA pol II [38]. Finally, as a poly (A) signal emerges on newly synthesized RNA, addition of a poly (A) tail to the $3^{\prime}$ end of the RNA is initiated by polyadenylation factors carried along by the elongating Pol II [35;70], which in turn promotes splicing of the RNA $3^{\prime}$ terminal intron $[102 ; 120 ; 161]$.

Pre-mRNA splicing involves five small U RNAs (U1, U2, U4, U5, and U6) and many splicing factors. Defining the exon-intron boundary is the first step in the accurate recognition of an intron $5^{\prime}$ ss and an intron $3^{\prime}$ ss. This involves interaction of the $5^{\prime}$ ss with U1 snRNP, of the branch site with U2 snRNP, and of the $3^{\prime}$ ss with $\mathrm{U}_{2} \mathrm{AF}^{65}$ and $\mathrm{U}^{2} \mathrm{AF}^{35}$ (a heterodimer of U2 auxiliary factors), modulated by many cellular splicing factors including serine/arginine-rich (SR) proteins [60]. SR proteins are a growing family of structurally related and highly conserved cellular splicing factors that are characterized by the presence of an RNArecognition motif (RRM) and Ser/Arg (SR) dipeptides. Over the past two decades, a great deal has been learnt about how RNA splicing takes place by using a yeast system and RNAs containing strong introns. Unfortunately, the majority of viral and mammalian introns have suboptimal (weak) features with non-consensus sequences at each splice site and branch sites for these interactions. Sometimes an authentic splice site is indistinguishable from a cryptic splice site embedded in a viral or mammalian pre-mRNA and identification of its usage has to rely solely on experimental analysis. This raises many intriguing questions of how the cellular splicing machinery defines an authentic splice site in a "sea of similarity".

\section{Alternative RNA splicing and proteomic diversity}

Constitutive RNA splicing describes the situation in which all introns on a pre-mRNA are spliced in the 5' ss to 3'ss order and all exons are represented in the spliced message. In contrast, alternative RNA splicing implies that an RNA splice site is not used constitutively; instead, additional splice sites can be used as alternatives to it during RNA splicing. Alternative RNA splicing usually occurs when the RNA bears a weak splice site and presumably is dependent on the local availability of the correct forms of splicing factors. Thus, alternative splicings of a particular RNA can be found in different cell types, at different stages of cell differentiation, or at different stages of viral life cycles. The consequence of alternative splicing is the generation of different isoforms of the RNA for production of different proteins required for specific functions (Fig. 1). In general, there are four types of alternative RNA splicing (Fig. 2): alternative $5^{\prime}$ splice site selection, alternative $3^{\prime}$ splice site selection, intron retention, and exon exclusion and skipping. Although the example given for each category provides a simplified form for a clearer description, complex RNA splicing that includes all four modes could be found on a single pre-mRNA bearing multiple exons and introns. In a few unusual 
cases, even exon repetition by trans-splicing and exon scrambling through RNA splicing and re-splicing have been described in mammalian gene expression [22;54;173].

Alternative RNA splicing has received little attention outside of RNA field since the discovery of exons and introns in the adenovirus in 1977 [9;28]. Recent reports of only 24,500 [92] to 26,588 [163] human genes, with an additional 5000-12,000 expected to be reported as geneprediction programs improve, came as a surprise for most scientists, who had predicted that the human genome would have up to 120,000 genes [103]. Ironically, the number of human protein-coding genes is just twice that in the fly genome, and about 5 times larger than that in yeast (Table 1)! However, the finding that almost every human gene, on average, has 4.7 to 7.2 exons, with the largest number of exons, 234, identified in titin transcripts [163], was another surprise. This report from Celera also estimated that the decoded human genome has approximately 17,764 genes (66.8\% of all human genes) that can produce alternatively spliced forms of the transcripts[163]. The number of human genes producing alternatively spliced transcripts is far more than that of any other species whose genome has been completely sequenced (Table 1). This is just one of many intriguing issues about the nature of genomic complexity. Conceivably, the complexity of a proteome is increased significantly by alternative RNA splicing rather than by transcriptional regulation. For example, alternative RNA splicing contributes over 1000 isoforms of neurexin transcripts that are expressed in distinct subsets of neurons [159]. As a result, it is an extreme challenge to sort out how neurons regulate such complex RNA splicing and the function each message specifies for a cell. A highly evolved mechanism must exist in the expression of a human gene to specify individual protein expression by precisely defining the selection of the correct isoform of the transcript. Recent studies have demonstrated that there are hundreds to thousands of cellular proteins that are associated with the regulation of RNA processing, and many of these are alternative RNA splicing factors [ $4 ; 66 ; 134 ; 182]$. Thus, it is understandable that, even before the human genome was completely decoded, aberrant RNA splicing was found to account for at least $15 \%$ of genetic diseases and some cancers [50].

Alternative RNA splicing has been extensively studied in viral gene expression ever since the discovery of RNA splicing. Viruses take advantage of alternative splicing to diversify their gene expression and thus to enlarge their proteomic potential with a limited genome. The adenovirus has served as a model since it was used in the discovery of RNA splicing [9;28]. Other well-understood systems are those of the papillomaviruses and HIV. Alternative viral RNA splicing in papillomavirus infection is associated with the virus life cycle and depends on the differentiation state of the keratinocyte host. HIV is a complex retrovirus that creates 46 different RNA transcripts by alternative splicing of a single genomic RNA for a total of 47 different mRNA species in the host [131]. Since viral RNA splicing utilizes the cellular splicing machinery (spliceosome) and is processed through the mammalian RNA splicing pathway, elucidation of viral RNA splicing control has provided much of our understanding of the regulation of mammalian RNA splicing over the past two decades, and will most likely continue to do so.

\section{Exon definition and alternative RNA splicing}

The definition of an exon presupposes that there is cross-talk between a $3^{\prime}$ ss and a $5^{\prime}$ ss over the exon, and that recognition of an upstream $3^{\prime}$ ss by the cellular splicing machinery can be strengthened by a downstream $5^{\prime}$ ss over the exon [8;71;76;88]. Accordingly, an oversized internal exon larger than 500 nucleotides (nts) would limit such cross-talk and splicing enhancement. This principle has been supported experimentally [148] and bioinformatically [174]. In fact, most mammalian pre-mRNAs contain very short exons, whereas the introns can be as large as tens of thousands of nts long. It is therefore often difficult to identify relatively small exons in the context of much larger non-coding intronic sequences. 
The definition of an exon in the regulation of alternative RNA splicing can be exemplified by the splicing of Kaposi's sarcoma-associated herpesvirus (KSHV) K8 RNA. KSHV K8 is an early gene and encodes for a K-bZIP protein involved in viral DNA replication [104]. KSHV $\mathrm{K} 8$ pre-mRNA has four exons and three introns, with exon 3 bearing three alternative $5^{\prime}$ splice sites (Fig. 3) at nts 75838, 76155, and 76338 [153]. Utilization of the nt $758385^{\prime}$ ss stimulates splicing at the upstream nt $756453^{\prime}$ ss and predominates over the other two $5^{\prime}$ ss during RNA splicing. A primary reason that the nt $758385^{\prime}$ ss is preferentially selected over the other two $5^{\prime}$ ss is that the small size of exon 3 might make the cross-talk between the $3^{\prime}$ ss and $5^{\prime}$ ss accessible over the exon.

Removal of the first intron from a pre-mRNA has been found to be cap-dependent. We recently showed that the size of an RNA 5'-terminal exon also affects the cap-dependent RNA splicing. We have concluded from various approaches that efficient splicing of a pre-mRNA depends on the distance of the cap-proximal intron 5' ss from the RNA 5' cap, with an optimal distance of less than $304 \mathrm{nts}$ (Zheng et al, unpublished observation). The large distance of a cap-proximal $5^{\prime}$ splice site from the RNA 5' cap in AAV2 P5- and P19-generated transcripts may explain why this splice site is not recognized by the cellular splicing machinery [132]. Simply put, the cap-proximal 5' ss will be easily selected if the cap-proximal exon is smaller than $304 \mathrm{nts}$. As a result, the RNA 5' cap-binding complex (CBC) strengthens recruitment of U1 or U6 to a capproximal 5' ss and mediates recognition of the cap-proximal 5' ss. An extensive computational analysis of 2139 human genes consistently revealed that the mean length of a gene's first partially coding or non-coding exon is less than $348 \mathrm{nts}$ [37].

\section{Exonic splicing enhancers}

As described above, the majority of viral and mammalian RNA introns are suboptimal, lacking consensus sequences in their splice sites. Instead of having a run of 15 to 40 pyrimidines (usually Us), the PPT between a branch site and a 3' ss AG dinucleotide in viral or mammalian RNA introns is generally interspersed with purines and has low binding affinity for splicing factor U2AF, which is essential for 3' ss recognition. How these suboptimal 3' ss are selected correctly has been a major focus of splicing research in the past decade. This effort led to the discovery of exon recognition elements, which were later renamed exonic splicing enhancers (ESEs) $[93 ; 150 ; 164 ; 170]$. The discovery of ESEs was exciting because they are distinct from the classical, intronic splicing signals.

Two classes of ESEs have been reported. The purine-rich ESEs are the most common and are usually located, with great vicinity, downstream of a suboptimal 3' ss [49]. ESEs stimulate splicing of the upstream intron at both steps of the two-step trans-esterification splicing reaction [26;180]. The natural purine-rich ESEs found in viral and mammalian exons consist of a core motif of alternate As and Gs, generally 6 nts or longer (Table 2); an A-run or G-run sequence in an exon does not function as a splicing enhancer [152]. A purine-rich ESE usually has one or more SR binding sites. Through interactions with a subset of SR proteins, purine-rich ESEs recruit or strengthen the binding of U2AF to a suboptimal, upstream $3^{\prime}$ splice site and stimulate spliceosome assembly $[61 ; 93 ; 150 ; 184]$. However, an exon sequence having one or more SR binding sites does not necessarily function as an ESE [178;179] and some of the exonic splicing suppressors (ESSs) also bind SR proteins [117;179]. A purine-rich element can also suppress splicing of a pre-mRNA when located in a regulated intron [56;84;181]. Thus, depending on the location and features of the regulated $3^{\prime}$ ss, a purine-rich ESE can function as an exonic splicing enhancer or an intronic splicing suppressor.

The other class of ESEs is the non-purine-rich ESE. This class includes the exonic AC-rich enhancer and exonic pyrimidine-rich enhancer (Table 2). The AC-rich enhancers were first identified by in vivo selection experiments and were found to stimulate splicing both in vivo 
and in vitro [32]. AC-rich ESEs have been shown to be involved in the regulated splicing of both viral and cellular genes [32;57;181]. Recent studies demonstrated that the AC-rich ESEs interact with a cold-shock cellular protein, Y box protein 1 (YB-1), to function in a manner similar to that of the purine-rich ESEs [149]. Exonic pyrimidine-rich enhancers have been described in $\beta$-globin RNA [137] and other mammalian RNAs [45;145].

\section{Exonic splicing suppressors}

Exonic splicing suppressors or silencers (ESS) (Table 2) were discovered ten years ago in the course of exploring ESEs and have been identified in many pre-mRNAs [2;39;146;176]. These cis-elements negatively regulate the utilization of upstream $3{ }^{\prime}$ splice sites. They are frequently located downstream of a juxtaposed ESE, but can also function upstream of an ESE [145; $166 ; 178]$. Unlike the ESEs, the sequences of the ESSs show little similarity to each other. However, each of the ESSs appears to contain a functional core motif that binds a number of cellular splicing factors. Seeking trans-acting factors for ESS function in the inhibition of RNA splicing was a major focus of research in the past six years, and the first breakthrough was the finding of multiple cellular splicing factors, the PTB, U2AF, and SR proteins, that bind to bovine papillomavirus type 1 (BPV-1) ESS1, a pyrimidine-rich ESS [179]. Subsequently, other cellular factors were also found to play a role in ESS function, including SC35 for the HIV-1 tat exon 3 ESS [117], hnRNP $\mathrm{H}$ for the rat $\beta$-tropomyosin exon 7 ESS [23], and hnRNP A1 for the FGFR 2 K-SAM ESS [41] and for the HIV-1 tat exon 2 ESS [17]. Moreover, the fibronectin EDA ESS has been also implicated in the maintenance of an RNA conformation that facilitates display of the adjacent ESE SR protein binding sequences [125].

Thus, ESSs may inhibit RNA splicing in vitro and in vivo through multiple mechanisms. Many ESSs appear to antagonize the activity of ESEs [83;176], and some of them are even both splice-site- and ESE-specific, such as BPV-1 ESS2 [181]; however, the exact mechanism by which ESSs act remains largely unknown. ESS splicing suppression in some viral or mammalian RNAs without notable ESEs, including an RSV src pre-mRNA [178] and FGFR-2 K-SAM [39;40], indicates that in some cases the function of the ESS is independent of an ESE. In addition, ESSs function, in most cases, only on suboptimal, alternative splice sites. Supporting this, the human $\beta$-globin pre-mRNA, which contains a constitutive, optimal (strong) $3^{\prime}$ ss, splices efficiently in the presence of a heterologous ESS [178], and optimization of a weak (suboptimal), alternatively regulated $3^{\prime}$ ss can also counteract the function of the ESS $[142 ; 146 ; 180]$.

\section{Regulation of alternative RNA splicing by ESEs and ESSs}

Although ESEs and ESSs are thought to be present in most if not all alternatively spliced exons, the mechanisms that regulate alternative RNA splicing are only partially understood. The accepted principles on how ESEs and ESSs function in vivo have largely been deduced from in vitro studies. Currently, there are two simplified models of how an ESE functions in ESEdependent RNA splicing. In the U2AF recruitment model, ESE-bound SR proteins interact with $\mathrm{U}_{2} \mathrm{AF}^{35}$ and recruit $\mathrm{U} 2 \mathrm{AF}^{65}$ to a weak $3^{\prime}$ ss. In this model, $\mathrm{U}^{2} \mathrm{AF}^{35}$ serves as a bridge between ESE-bound SR proteins and U2AF ${ }^{65}$ through protein-protein interactions [62;184]. The existence of ESEs that exclusively bind SR proteins favors this model, but this model does not initially take ESSs into account, and disregards how an ESE overcomes the splicing suppression of an ESS. The second model, the ESE neutralization model, hypothesizes that the primary function of an ESE in an exon is to antagonize the function of an ESS within the same exon, rather than to recruit U2AF to an upstream $3^{\prime}$ ss [83]. This model is supported by evidence that removal of an ESS can enable splicing in the absence of the enhancer, that is, ESE-independent splicing can occur. However, alternative splice sites on viral and mammalian pre-mRNAs commonly have nonconsensus splicing signals and would not be recognized 
efficiently by the cellular splicing machinery in the absence of an ESE, precluding the generality of the latter model. Along with the elucidation of the intrinsic properties of ESEs and ESSs, several excellent studies in model systems have provided convincing evidence that alternative RNA splicing regulated by ESEs and ESSs in physiological conditions depends on many variables, including the presence of multiple RNA cis-elements, the strength of the splicing signals, the cell type, and the cell activation and differentiation status, as well as the stage of viral infection. Thus, beside exon cis-elements on an RNA, the availability of transacting splicing factors and their physiological (modification) status in a defined environment play important roles in ESE-and ESS-regulated RNA splicing.

\section{Regulation of alternative 3' ss selection in splicing of BPV-1 late pre-mRNA}

Regulation of alternative 3' ss selection by ESEs and ESSs has been extensively studied in the BPV-1 late pre-mRNA. The primary transcripts expressed from the viral late promoter have a common late leader 5' ss, but use a proximal or a distal 3' ss for RNA splicing. Splicing at the proximal 3' ss leads to the production of L2 mRNA, whereas splicing at the distal 3'ss results in the production of L1 mRNA. In situ hybridization studies demonstrated that the distal 3' ss is utilized only in the granular cell layer of the epidermis, while selection of the proximal $3^{\prime}$ ss occurs in both the granular and spinous layers [6]. Recent studies show that this differentiationspecific alternative $3^{\prime}$ ss selection is related to the suboptimal features of both the proximal and distal 3'ss and is regulated by five viral cis-elements: three ESEs and two ESSs. Among these elements, three cis-acting elements, SE1, SE2, and ESS1, are positioned between the proximal and the distal 3' ss, with ESS1 immediately downstream of SE1 and 122 nts upstream of SE2 (Fig. 4A). These elements regulate the selection of the proximal 3' ss for RNA splicing [176; $177 ; 179 ; 180]$, whereas two other elements, SE4 and ESS2, are located downstream of the distal $3^{\prime}$ ss and control selection of the distal $3^{\prime}$ ss [181]. Thus, the five cis-elements interact in a coordinate fashion to specify which $3^{\prime}$ ss should be used. Any subtle changes that disrupt this coordinate balance can provoke a switch from one $3^{\prime}$ ss to another.

BPV-1 SE1 and SE2 are purine-rich ESEs and each has at least two ASF/SF2 binding sites, although others may exist [177]. BPV-1 ESS1 is composed of a 48-nt pyrimidine-rich sequence and has a U-rich 5' region interacting with $\mathrm{U} 2 \mathrm{AF}$ and $\mathrm{PTB}$ proteins, a $\mathrm{C}$-rich central part binding 35- and 54-55 kDa SR proteins, and an AG-rich 3' end favoring ASF/SF2 interaction [179]. Although it binds to PTB and U2AF ${ }^{65}$, the $5^{\prime} \mathrm{U}$-rich region of ESS1 appears not to be essential for the inhibition of splicing in vitro [178;179] or in vivo [180]. Various approaches have shown that SE1 and SE2 synergistically promote the selection of the proximal 3' ss over the suppression by ESS1 [180], presumably by interacting with SR proteins such as ASF/SF2, since mutation of either one of the two ASF/SF2 binding sites within either SE1 or SE2 switches the selection to the distal 3' ss. Deletion or mutation of the ESS1central suppressor core GGCUCCCC, which also binds SR proteins but does not stimulate splicing [178;179], does not affect selection of the proximal 3' ss. The same is true of ESS1 and SE2 double mutations; in this context, SE1 enhances the RNA splicing at the proximal 3' ss in the absence of a functional ESS1 and SE2 [180]. The importance of ASF/SF2 in the selection of the proximal $3^{\prime}$ ss has been further verified under physiological conditions, where depletion of ASF/SF2 from cells decreases BPV-1 late RNA splicing at the proximal 3' ss with a reciprocal increase in utilization of the distal 3' ss [106]. This switch is also regulated by an AC-rich ESE, SE4, and an ESS2 downstream [181]. Accordingly, the mutation in SE4 can turn the distal 3' ss usage back to the proximal 3'ss usage. In a BPV-1 late pre-mRNA containing a mutant SE2, a mutation in SE4 can cause the splicing machinery to revert to using the proximal $3^{\prime}$ ss instead of the distal 3' ss (Liu and Zheng, et al, unpublished data), indicating that it functions in vivo. SE4 and ESS2 functionally resemble SE1 and ESS1 in the selection of an alternative, suboptimal 3' ss, probably through interactions with the cellular protein YB-1 [149]. The overexpression of YB-1 by transient transfection increases utilization of the distal 3' ss, supporting 
this assumption (Zheng, et al., unpublished data). Although SE4 functions as an ESE for heterologous 3' ss, BPV-1 ESS2 apparently operates in a 3' splice site-specific and enhancerspecific manner [181]. It will be interesting to understand how ESS2 plays a suppressive role in the SE4-mediated RNA splicing. In summary, regulation of the usage of two alternative 3' ss in the splicing of BPV-1 late pre-mRNAs is an intricate network of viral exonic cis-elements which is governed closely by cellular splicing factors in accordance with the stage of keratinocyte differentiation.

\section{Regulation of alternative 5' ss selection in splicing of adenovirus E1A pre-mRNA}

Compared to the regulated selection of $3^{\prime}$ ss, there are only a few examples of ESE-regulated natural $5^{\prime}$ ss selection. Perhaps this is largely because recognition of the $5^{\prime}$ ss and the first step of RNA splicing are independent of the 5' exon sequence. In fact, an adML RNA containing only $1 \mathrm{nt}$ of $5^{\prime}$ exon sequence and having a downstream intron can undergo the first step of the splicing reaction in the presence of SR proteins [68]. This observation is consistent with several earlier reports that cellular splicing factors are involved in the regulation of alternative $5^{\prime}$ ss selection. This has been learnt largely from using ad2 E1A pre-mRNA as a model to analyze how SR proteins regulate alternative $5^{\prime}$ ss usage. Ad2 E1A pre-mRNA has three $5^{\prime}$ ss and one major and one minor $3^{\prime}$ ss. Alternative splicing of the three $5^{\prime}$ ss during early and late periods of the viral infection produces three main spliced RNA products: 9S, 12S, and 13S (Fig. 4B), among which the 13S RNA predominates during the early viral infection and the 9S RNA accumulates late in the infection. The 13S RNA encodes for a full-length oncoprotein, E1A. A number of studies have demonstrated that individual SR and non-SR proteins play roles in the selection of each alternative $5^{\prime}$ ss and in the shift from 13S to 9S RNA production. One interesting observation is that the $13 \mathrm{~S}$-to-9S transition can be triggered through a titration of the SR proteins 9G8, SC35, and ASF/SF2 by major-late transcripts that accumulate in nuclei late in the infection [69]. ASF/SF2 was the first of these that was found to relate to the selection of the $13 \mathrm{~S} 5^{\prime}$ ss, but its role in this $5^{\prime}$ ss selection can be antagonized by overexpressed hnRNA A1 [14;116]. Later, SRp40 [138] and SRp54 [175], and more recently TLS [99] and RBM4 [91], were found to preferentially activate the $9 \mathrm{~S} 5^{\prime}$ ss. However, lack of a specific binding site upstream of the $13 \mathrm{~S}$ and $9 \mathrm{~S} 5^{\prime}$ ss for these proteins suggests that individual splicing regulators of the 5 'ss selection site might function in an RNA sequence-independent manner (Fig. 4B). Interestingly, recent identification of a purine-rich ESE located immediately upstream of the $12 \mathrm{~S} 5^{\prime} \mathrm{ss}$, and demonstration that such an ESE is involved in selection of the 12S 5' ss through binding to SR protein 9G8, suggests that at least one of the 5' ss on ad2 E1A pre-mRNA is preferentially selected in an ESE-dependent manner [11]. Likewise, a 32-nt ESE positioned between two regulated $5^{\prime}$ ss in exon 5 of the caldesmon pre-mRNA has been also found to stimulate the use of the upsteam $5^{\prime}$ ss and to regulate usage of a competing $5^{\prime}$ ss in a differential internal exon [48;75]. There have been no reports of ESS-regulated selection of alternative 5' ss.

\section{Remarks and perspectives}

The hallmark discovery in the past decade of exon cis-elements involved in regulating RNA splicing has changed our view that the only function of exon sequences is to encode proteins. That the splicing of minor AU-AC introns in vivo [43] and in vitro [168] also responds to purine-rich enhancers indicates that ESE- and ESS-regulated RNA splicing has effects well beyond that of the regulated splicing of major GU-AG introns. Although this review mainly focuses on the roles of exon sequences in the regulation of alternative RNA splicing of major GU-AG introns, the many other functions displayed by exon sequences should not be ignored. For example, exon sequences have recently been found to be responsible for nonsensemediated RNA decay (NMD) and for nuclear export of spliced mRNAs. An exon region 20-24 nts upstream of a splice junction provides a binding site for several cellular proteins of the exon 
junction complex (EJC) that may function in NMD [86;109]. NMD degrades RNA that has a premature termination codon (PTC) $>50-55$ nts upstream of a 3'-most exon-exon junction [113;122], and is a means to prevent the synthesis of potentially harmful truncated proteins due to aberrant or alternative RNA splicing. Other components of the EJC, such as REF/Aly, could interact with the mRNA export receptor TAP to facilitate mRNA export $[87 ; 95 ; 135$; 183]. Taken together, there is no reason not to accept that alternative RNA splicing expands the diversity of the genome, while creating another layer in which to check the integrity of messages and to destroy unwanted ones before a protein harmful to the host is made. The finding that $35 \%$ of EST-suggested, alternatively spliced RNA isoforms carrying PTCs are apparent targets for NMD [100] makes this house-keeping hypothesis more plausible.

Moreover, exon sequences on 3 ' terminal exons have been also characterized as regulating RNA polyadenylation [15;151] and in defining the length of the RNA poly (A) tail [63;64].

Perhaps the most remarkable advance in the characterization of ESEs/ESSs is the finding that a single nt mutation within an ESE or ESS can lead to alternative RNA splicing that is associated with a genetic disorder or cancer. A single-base-change ( $\mathrm{C}$ to $\mathrm{U}$ ) at position +6 in SMN2 exon 7 converts an ASF/SF2-binding sequence [20] into an ESS that binds hnRNP A1 [85]. This mutation prevents efficient exon 7 splicing promoted by a downstream, Tra2-dependent, purine-rich ESE $[72 ; 107]$ and results in the skipping of exon 7 during the splicing of SMN2 RNA (Fig. 5). The BRCA1 gene in breast cancer has a $\mathrm{G}$ to $\mathrm{U}$ mutation at position +6 of exon 18 that disrupts the function of an ESE. This single-base mutation converts a high-score SF2/ ASF motif (CUGAGUU) into a low-score SF2/ASF motif (CUUAGUU), and consequently leads to the skipping of exon 18 in the spliced BRCA1 mRNA and a C-terminal-truncated BRCA1 [21;105;118]. Together, these two studies exemplify the profound potential influence of single nucleotide polymorphisms on post-transcriptional events and the pathogenesis of genetic disorders and cancers. Thus, disease-related disruption and/or creation of ESE/ESS may well be a continuing, prospective focus in RNA splicing research.

The cell- or tissue-specific expression of splicing factors that regulate alternative RNA splicing has provided some fundamental insight into how alternative RNA splicing takes place in a cellor tissue-specific manner. Regulation of the 4.1R exon 16 (E16) splicing switch by hnRNP A/ $B$ protein during erythropoiesis provides an excellent example. Expression of the human 4.1R gene is necessary for erythrocyte membrane formation. Erythrocyte membranes containing a 4.1R protein that lacks E16 coding sequences due to E16 skipping are very susceptible to shear forces, which could lead to hemolytic anemia. The 4.1R E16 contains an ESS that specifically interacts with hnRNP A/B proteins and inhibits E16 inclusion in the spliced 4.1R mRNA. Interestingly, this inhibition is relieved in differentiated erythroblasts. Declining expression of hnRNP A/B during erythroid differentiation has been correlated with increased E16 inclusion in the 4.1R mRNA [74] This indicates that natural developmental changes in hnRNP A/B proteins can affect physiologically important switches in pre-mRNA splicing. Gaining further understanding of how the expression of specific splicing factor(s) in specific tissues and cells contributes to the regulation of alternative RNA splicing will be a challenge, but may deliver the next wave of discoveries in RNA research.

\section{Reference List}

1. Akusjarvi G, Stevenin J. Remodelling of the host cell RNA splicing machinery during an adenovirus infection. Curr Top Microbiol Immunol 2003;272:253-286. [PubMed: 12747553]

2. Amendt BA, Hesslein D, Chang L-J, Stoltzfus CM. Presence of negative and positive cis-acting RNA splicing elements within and flanking the first tat coding exon of human immunodeficiency virus type 1. Mol Cell Biol 1994;14:3960-3970. [PubMed: 8196635] 
3. Amendt BA, Si Z-H, Stoltzfus CM. Presence of exon splicing silencers within human immunodeficiency virus type 1 tat exon 2 and tat-rev exon 3: Evidence for inhibition mediated by cellular factors. Mol Cell Biol 1995;15:4606-4615. [PubMed: 7623852]

4. Andersen JS, Lyon CE, Fox AH, Leung AK, Lam YW, Steen H, Mann M, Lamond AI. Directed proteomic analysis of the human nucleolus. Curr Biol 2002;12:1-11. [PubMed: 11790298]

5. Aznarez I, Chan EM, Zielenski J, Blencowe BJ, Tsui LC. Characterization of disease-associated mutations affecting an exonic splicing enhancer and two cryptic splice sites in exon 13 of the cystic fibrosis transmembrane conductance regulator gene. Hum Mol Genet 2003;12:2031-2040. [PubMed: 12913074]

6. Barksdale SK, Baker CC. Differentiation-specific alternative splicing of bovine papillomavirus late mRNAs. J Virol 1995;69:6553-6556. [PubMed: 7666558]

7. Battaglia G, Princivalle A, Forti F, Lizier C, Zeviani M. Expression of the SMN gene, the spinal muscular atrophy determining gene, in the mammalian central nervous system. Hum Mol Genet 1997;6:1961-1971. [PubMed: 9302277]

8. Berget SM. Exon recognition in vertebrate splicing. J Biol Chem 1995;270:2411-2414. [PubMed: 7852296]

9. Berget SM, Moore C, Sharp PA. Spliced segments at the 5' terminus of adenovirus 2 late mRNA. Proc Natl Acad Sci USA 1977;74:3171-3175. [PubMed: 269380]

10. Bilodeau PS, Domsic JK, Mayeda A, Krainer AR, Stoltzfus CM. RNA splicing at human immunodeficiency virus type $13^{\prime}$ splice site A2 is regulated by binding of hnRNP A/B proteins to an exonic splicing silencer element. J Virol 2001;75:8487-8497. [PubMed: 11507194]

11. Bourgeois CF, Popielarz M, Hildwein G, Stevenin J. Identification of a bidirectional splicing enhancer: differential involvement of SR proteins in 5' or 3' splice site activation. Mol Cell Biol 1999;19:7347-7356. [PubMed: 10523623]

12. Brichta L, Hofmann Y, Hahnen E, Siebzehnrubl FA, Raschke H, Blumcke I, Eyupoglu IY, Wirth B. Valproic acid increases the SMN2 protein level: a well-known drug as a potential therapy for spinal muscular atrophy. Hum Mol Genet 2003;12:2481-2489. [PubMed: 12915451]

13. Buvoli M, Mayer SA, Patton JG. Functional crosstalk between exon enhancers, polypyrimidine tracts and branchpoint sequences. EMBO J 1997;16:7174-7183. [PubMed: 9384594]

14. Caceres JF, Stamm S, Helfman DM, Krainer AR. Regulation of alternative splicing in vivo by overexpression of antagonistic splicing factors. Science 1994;265:1706-1709. [PubMed: 8085156]

15. Calvo O, Manley JL. Strange bedfellows: polyadenylation factors at the promoter. Genes Dev 2003;17:1321-1327. [PubMed: 12782649]

16. Caputi M, Casari G, Guenzi S, Tagliabue R, Sidoli A, Melo CA, Baralle FE. A novel bipartite splicing enhancer modulates the differential processing of the human fibronectin EDA exon. Nucleic Acids Res 1994;22:1018-1022. [PubMed: 8152907]

17. Caputi M, Mayeda A, Krainer AR, Zahler AM. hnRNP A/B proteins are required for inhibition of HIV-1 pre-mRNA splicing. EMBO J 1999;18:4060-4067. [PubMed: 10406810]

18. Caputi M, Zahler AM. SR proteins and hnRNP H regulate the splicing of the HIV-1 tev-specific exon 6D. EMBO J 2002;21:845-855. [PubMed: 11847131]

19. Cartegni L, Chew SL, Krainer AR. Listening to silence and understanding nonsense: exonic mutations that affect splicing. Nat Rev Genet 2002;3:285-298. [PubMed: 11967553]

20. Cartegni L, Krainer AR. Disruption of an SF2/ASF-dependent exonic splicing enhancer in SMN2 causes spinal muscular atrophy in the absence of SMN1. Nat Genet 2002;30:377-384. [PubMed: 11925564]

21. Cartegni L, Krainer AR. Correction of disease-associated exon skipping by synthetic exon-specific activators. Nat Struct Biol 2003;10:120-125. [PubMed: 12524529]

22. Caudevilla C, Serra D, Miliar A, Codony C, Asins G, Bach M, Hegardt FG. Natural trans-splicing in carnitine octanoyltransferase pre-mRNAs in rat liver. Proc Natl Acad Sci USA 1998;95:1218512190. [PubMed: 9770461]

23. Chen CD, Kobayashi R, Helfman DM. Binding of hnRNP H to an exonic splicing silencer is involved in the regulation of alternative splicing of the rat beta-tropomyosin gene. Genes Dev 1999;13:593606. [PubMed: 10072387] 
24. Chen Y, Sumiyoshi H, Oxford JT, Yoshioka H, Ramirez F, Morris NP. Cis-acting elements regulate alternative splicing of exons $6 \mathrm{~A}, 6 \mathrm{~B}$ and 8 of the alpha1(XI) collagen gene and contribute to the regional diversification of collagen XI matrices. Matrix Biol 2001;20:589-599. [PubMed: 11731275]

25. Chew SL, Baginsky L, Eperon IC. An exonic splicing silencer in the testes-specific DNA ligase III beta exon. Nucleic Acids Res 2000;28:402-410. [PubMed: 10606636]

26. Chew SL, Liu HX, Mayeda A, Krainer AR. Evidence for the function of an exonic splicing enhancer after the first catalytic step of pre-mRNA splicing. Proc Natl Acad Sci USA 1999;96:10655-10660. [PubMed: 10485881]

27. Chiu YL, Ho CK, Saha N, Schwer B, Shuman S, Rana TM. Tat stimulates cotranscriptional capping of HIV mRNA. Mol Cell 2002;10:585-597. [PubMed: 12408826]

28. Chow LT, Gelinas RE, Broker TR, Roberts RJ. An amazing sequence arrangement at the 5 ' ends of adenovirus 2 messenger RNA. Cell 1977;12:1-8. [PubMed: 902310]

29. Chung H, Derse D. Binding sites for Rev and ASF/SF2 map to a 55-nucleotide purine-rich exonic element in equine infectious anemia virus RNA. J Biol Chem 2001;276:18960-18967. [PubMed: 11278454]

30. Coovert DD, Le TT, McAndrew PE, Strasswimmer J, Crawford TO, Mendell JR, Coulson SE, Androphy EJ, Prior TW, Burghes AH. The survival motor neuron protein in spinal muscular atrophy. Hum Mol Genet 1997;6:1205-1214. [PubMed: 9259265]

31. Cote J, Simard MJ, Chabot B. An element in the 5' common exon of the NCAM alternative splicing unit interacts with SR proteins and modulates 5' splice site selection. Nucleic Acids Res 1999;27:2529-2537. [PubMed: 10352182]

32. Coulter LR, Landree MA, Cooper TA. Identification of a new class of exonic splicing enhancers by in vivo selection. Mol Cell Biol 1997;17:2143-2150. [PubMed: 9121463]

33. Cramer P, Caceres JF, Cazalla D, Kadener S, Muro AF, Baralle FE, Kornblihtt AR. Coupling of transcription with alternative splicing: RNA pol II promoters modulate SF2/ASF and 9G8 effects on an exonic splicing enhancer. Mol Cell 1999;4:251-258. [PubMed: 10488340]

34. D’Souza I, Schellenberg GD. Determinants of 4-repeat tau expression. Coordination between enhancing and inhibitory splicing sequences for exon 10 inclusion. J Biol Chem 2000;275:17700 17709. [PubMed: 10748133]

35. Dantonel JC, Murthy KG, Manley JL, Tora L. Transcription factor TFIID recruits factor CPSF for formation of 3' end of mRNA. Nature 1997;389:399-402. [PubMed: 9311784]

36. Davis CA, Grate L, Spingola M, Ares M Jr. Test of intron predictions reveals novel splice sites, alternatively spliced mRNAs and new introns in meiotically regulated genes of yeast. Nucleic Acids Res 2000;28:1700-1706. [PubMed: 10734188]

37. Davuluri RV, Grosse I, Zhang MQ. Computational identification of promoters and first exons in the human genome. Nat Genet 2001;29:412-417. [PubMed: 11726928]

38. de la Mata M, Alonso CR, Kadener S, Fededa JP, Blaustein M, Pelisch F, Cramer P, Bentley DL, Kornblihtt AR. A Slow RNA Polymerase II Affects Alternative Splicing In Vivo. Mol Cell 2003;12:525-532. [PubMed: 14536091]

39. Del Gatto F, Breathnach R. Exon and intron sequences, respectively, repress and activate splicing of a fibroblast growth factor receptor 2 alternative exon. Mol Cell Biol 1995;15:4825-4834. [PubMed: 7651400]

40. Del Gatto F, Gesnel MC, Breathnach R. The exon sequence TAGG can inhibit splicing. Nucleic Acids Res 1996;24:2017-2021. [PubMed: 8668531]

41. Del Gatto-Konczak F, Olive M, Gesnel MC, Breathnach R. hnRNP A1 recruited to an exon in vivo can function as an exon splicing silencer. Mol Cell Biol 1999;19:251-260. [PubMed: 9858549]

42. DiDonato CJ, Lorson CL, De Repentigny Y, Simard L, Chartrand C, Androphy EJ, Kothary R. Regulation of murine survival motor neuron (Smn) protein levels by modifying Smn exon 7 splicing. Hum Mol Genet 2001;10:2727-2736. [PubMed: 11726560]

43. Dietrich RC, Shukla GC, Fuller JD, Padgett RA. Alternative splicing of U12-dependent introns in vivo responds to purine-rich enhancers. RNA 2001;7:1378-1388. [PubMed: 11680842]

44. Dirksen WP, Hampson RK, Sun Q, Rottman FM. A purine-rich exon sequence enhances alternative splicing of bovine growth hormone pre-mRNA. J Biol Chem 1994;269:6431-6436. [PubMed: 8119993] 
45. Dirksen WP, Mohamed SA, Fisher SA. Splicing of a myosin phosphatase targeting subunit 1 alternative exon is regulated by intronic cis-elements and a novel bipartite exonic enhancer/silencer element. J Biol Chem 2003;278:9722-9732. [PubMed: 12509424]

46. Dreyfuss G, Kim VN, Kataoka N. Messenger-RNA-binding proteins and the messages they carry. Nat Rev Mol Cell Biol 2002;3:195-205. [PubMed: 11994740]

47. Dye BT, Buvoli M, Mayer SA, Lin CH, Patton JG. Enhancer elements activate the weak 3' splice site of alpha-tropomyosin exon 2. RNA 1998;4:1523-1536. [PubMed: 9848651]

48. Elrick LL, Humphrey MB, Cooper TA, Berget SM. A short sequence within two purine-rich enhancers determines 5' splice site specificity. Mol Cell Biol 1998;18:343-352. [PubMed: 9418881]

49. Fairbrother WG, Yeh RF, Sharp PA, Burge CB. Predictive identification of exonic splicing enhancers in human genes. Science 2002;297:1007-1013. [PubMed: 12114529]

50. Faustino NA, Cooper TA. Pre-mRNA splicing and human disease. Genes Dev 2003;17:419-437. [PubMed: 12600935]

51. Feldkotter M, Schwarzer V, Wirth R, Wienker TF, Wirth B. Quantitative analyses of SMN1 and SMN2 based on real-time lightCycler PCR: fast and highly reliable carrier testing and prediction of severity of spinal muscular atrophy. Am J Hum Genet 2002;70:358-368. [PubMed: 11791208]

52. Fong N, Bentley DL. Capping, splicing, and 3' processing are independently stimulated by RNA polymerase II: different functions for different segments of the CTD. Genes Dev 2001;15:17831795. [PubMed: 11459828]

53. Fong YW, Zhou Q. Stimulatory effect of splicing factors on transcriptional elongation. Nature 2001;414:929-933. [PubMed: 11780068]

54. Frantz SA, Thiara AS, Lodwick D, Ng LL, Eperon IC, Samani NJ. Exon repetition in mRNA. Proc Natl Acad Sci USA 1999;96:5400-5405. [PubMed: 10318895]

55. Galiana-Arnoux D, Lejeune F, Gesnel MC, Stevenin J, Breathnach R, Gatto-Konczak F. The CD44 alternative v9 exon contains a splicing enhancer responsive to the SR proteins 9G8, ASF/SF2, and SRp20. J Biol Chem 2003;278:32943-32953. [PubMed: 12826680]

56. Gallego ME, Gattoni R, Stevenin J, Marie J, Expert-Bezancon A. The SR splicing factors ASF/SF2 and SC35 have antagonistic effects on intronic enhancer-dependent splicing of the beta-tropomyosin alternative exon 6A. EMBO J 1997;16:1772-1784. [PubMed: 9130721]

57. Gersappe A, Pintel DJ. CA- and purine-rich elements form a novel bipartite exon enhancer which governs inclusion of the minute virus of mice NS2-specific exon in both singly and doubly spliced mRNAs. Mol Cell Biol 1999;19:364-375. [PubMed: 9858560]

58. Gontarek RR, Derse D. Interactions among SR proteins, an exonic splicing enhancer, and a lentivirus Rev protein regulate alternative splicing. Mol Cell Biol 1996;16:2325-2331. [PubMed: 8628299]

59. Graham IR, Hamshere M, Eperon IC. Alternative splicing of a human alpha-tropomyosin musclespecific exon: identification of determining sequences. Mol Cell Biol 1992;12:3872-3882. [PubMed: 1508190]

60. Graveley BR. Sorting out the complexity of SR protein functions. RNA 2000;6:1197-1211. [PubMed: 10999598]

61. Graveley BR, Hertel KJ, Maniatis T. A systematic analysis of the factors that determine the strength of pre-mRNA splicing enhancers. EMBO J 1998;17:6747-6756. [PubMed: 9822617]

62. Graveley BR, Hertel KJ, Maniatis T. The role of U2AF35 and U2AF65 in enhancer-dependent splicing. RNA 2001;7:806-818. [PubMed: 11421359]

63. Gu H, Das GJ, Schoenberg DR. The poly(A)-limiting element is a conserved cis-acting sequence that regulates poly(A) tail length on nuclear pre-mRNAs. Proc Natl Acad Sci USA 1999;96:8943-8948. [PubMed: 10430875]

64. Gupta JD, Gu H, Schoenberg DR. Position and sequence requirements for poly(A) length regulation by the poly(A) limiting element. RNA 2001;7:1034-1042. [PubMed: 11453064]

65. Haider MZ, Moosa A, Dalal H, Habib Y, Reynold L. Gene deletion patterns in spinal muscular atrophy patients with different clinical phenotypes. J Biomed Sci 2001;8:191-196. [PubMed: 11287750]

66. Hartmuth K, Urlaub H, Vornlocher HP, Will CL, Gentzel M, Wilm M, Luhrmann R. Protein composition of human prespliceosomes isolated by a tobramycin affinity-selection method. Proc Natl Acad Sci USA 2002;99:16719-16724. [PubMed: 12477934] 
67. Hayakawa M, Sakashita E, Ueno E, Tominaga S, Hamamoto T, Kagawa Y, Endo H. Muscle-specific exonic splicing silencer for exon exclusion in human ATP synthase gamma-subunit pre-mRNA. J Biol Chem 2002;277:6974-6984. [PubMed: 11744705]

68. Hertel KJ, Maniatis T. Serine-arginine (SR)-rich splicing factors have an exon-independent function in pre-mRNA splicing. Proc Natl Acad Sci USA 1999;96:2651-2655. [PubMed: 10077565]

69. Himmelspach M, Cavaloc Y, Chebli K, Stevenin J, Gattoni R. Titration of serine/arginine (SR) splicing factors during adenoviral infection modulates E1A pre-mRNA alternative splicing. RNA 1995;1:794-806. [PubMed: 7493325]

70. Hirose Y, Manley JL. RNA polymerase II is an essential mRNA polyadenylation factor. Nature 1998;395:93-96. [PubMed: 9738505]

71. Hoffman BE, Grabowski PJ. U1 snRNP targets an essential splicing factor, U2AF65, to the 3' splice site by a network of interactions spanning the exon. Genes Dev 1992;6:2554-2568. [PubMed: 1285125]

72. Hofmann Y, Lorson CL, Stamm S, Androphy EJ, Wirth B. Htra2-beta 1 stimulates an exonic splicing enhancer and can restore full-length SMN expression to survival motor neuron 2 (SMN2). Proc Natl Acad Sci USA 2000;97:9618-9623. [PubMed: 10931943]

73. Hofmann Y, Wirth B. hnRNP-G promotes exon 7 inclusion of survival motor neuron (SMN) via direct interaction with Htra2-beta1. Hum Mol Genet 2002;11:2037-2049. [PubMed: 12165565]

74. Hou VC, Lersch R, Gee SL, Ponthier JL, Lo AJ, Wu M, Turck CW, Koury M, Krainer AR, Mayeda A, Conboy JG. Decrease in hnRNP A/B expression during erythropoiesis mediates a pre-mRNA splicing switch. EMBO J 2002;21:6195-6204. [PubMed: 12426391]

75. Humphrey MB, Bryan J, Cooper TA, Berget SM. A 32-nucleotide exon-splicing enhancer regulates usage of competing 5' splice sites in a differential internal exon. Mol Cell Biol 1995;15:3979-3988. [PubMed: 7623794]

76. Hwang DY, Cohen JB. Base pairing at the 5' splice site with U1 small nuclear RNA promotes splicing of the upstream intron but may be dispensable for slicing of the downstream intron. Mol Cell Biol 1996;16:3012-3022. [PubMed: 8649413]

77. Ichida M, Hakamata Y, Hayakawa M, Ueno E, Ikeda U, Shimada K, Hamamoto T, Kagawa Y, Endo H. Differential regulation of exonic regulatory elements for muscle-specific alternative splicing during myogenesis and cardiogenesis. J Biol Chem 2000;275:15992-16001. [PubMed: 10821853]

78. Izaurralde E, Lewis J, McGuigan C, Jankowska M, Darzynkiewicz E, Mattaj IW. A nuclear cap binding protein complex involved in pre-mRNA splicing. Cell 1994;78:657-668. [PubMed: 8069914]

79. Jacquenet S, Mereau A, Bilodeau PS, Damier L, Stoltzfus CM, Branlant C. A second exon splicing silencer within human immunodeficiency virus type 1 tat exon 2 represses splicing of Tat mRNA and binds protein hnRNP H. J Biol Chem 2001;276:40464-40475. [PubMed: 11526107]

80. Jiang Z, Tang H, Havlioglu N, Zhang X, Stamm S, Yan R, Wu JY. Mutations in tau gene exon 10 associated with FTDP-17 alter the activity of an exonic splicing enhancer to interact with Tra2 beta. J Biol Chem 2003;278:18997-19007. [PubMed: 12649279]

81. Jin W, Huang ES, Bi W, Cote GJ. Exon sequence is required for regulated RNA splicing of the human fibroblast growth factor receptor-1 alpha-exon. J Biol Chem 1998;273:16170-16176. [PubMed: 9632672]

82. Kammler S, Leurs C, Freund M, Krummheuer J, Seidel K, Tange TO, Lund MK, Kjems J, Scheid A, Schaal $\mathrm{H}$. The sequence complementarity between HIV-1 5' splice site SD4 and U1 snRNA determines the steady-state level of an unstable env pre-mRNA. RNA 2001;7:421-434. [PubMed: 11333022]

83. Kan JL, Green MR. Pre-mRNA splicing of IgM exons M1 and M2 is directed by a juxtaposed splicing enhancer and inhibitor. Genes Dev 1999;13:462-471. [PubMed: 10049361]

84. Kanopka A, Muhlemann O, Akusjarvi G. Inhibition by SR proteins of splicing of a regulated adenovirus pre-mRNA. Nature 1996;381:535-538. [PubMed: 8632829]

85. Kashima T, Manley JL. A negative element in SMN2 exon 7 inhibits splicing in spinal muscular atrophy. Nat Genet 2003;34:460-463. [PubMed: 12833158]

86. Kim VN, Kataoka N, Dreyfuss G. Role of the nonsense-mediated decay factor hUpf 3 in the splicingdependent exon-exon junction complex. Science 2001;293:1832-1836. [PubMed: 11546873] 
87. Kim VN, Yong J, Kataoka N, Abel L, Diem MD, Dreyfuss G. The Y14 protein communicates to the cytoplasm the position of exon-exon junctions. EMBO J 2001;20:2062-2068. [PubMed: 11296238]

88. Kreivi JP, Zefrivitz K, Akusjarvi G. A U1 snRNA binding site improves the efficiency of in vitro pre-mRNA splicing. Nucleic Acids Res 1991;19:6956. [PubMed: 1762927]

89. Kwek KY, Murphy S, Furger A, Thomas B, O’Gorman W, Kimura H, Proudfoot NJ, Akoulitchev A. U1 snRNA associates with TFIIH and regulates transcriptional initiation. Nat Struct Biol 2002;9:800-805. [PubMed: 12389039]

90. Ladd AN, Cooper TA. Finding signals that regulate alternative splicing in the post-genomic era. Genome Biol 2002;3:reviews0008. [PubMed: 12429065]

91. Lai MC, Kuo HW, Chang WC, Tarn WY. A novel splicing regulator shares a nuclear import pathway with SR proteins. EMBO J 2003;22:1359-1369. [PubMed: 12628928]

92. Lander ES, Linton LM, Birren B, Nusbaum C, Zody MC, Baldwin J, Devon K, Dewar K, Doyle M, FitzHugh W, Funke R, Gage D, Harris K, Heaford A, Howland J, Kann L, Lehoczky J, LeVine R, McEwan P, McKernan K, Meldrim J, Mesirov JP, Miranda C, Morris W, Naylor J, Raymond C, Rosetti M, Santos R, Sheridan A, Sougnez C, Stange-Thomann N, Stojanovic N, Subramanian A, Wyman D, Rogers J, Sulston J, Ainscough R, Beck S, Bentley D, Burton J, Clee C, Carter N, Coulson A, Deadman R, Deloukas P, Dunham A, Dunham I, Durbin R, French L, Grafham D, Gregory S, Hubbard T, Humphray S, Hunt A, Jones M, Lloyd C, McMurray A, Matthews L, Mercer S, Milne S, Mullikin JC, Mungall A, Plumb R, Ross M, Shownkeen R, Sims S, Waterston RH, Wilson RK, Hillier LW, McPherson JD, Marra MA, Mardis ER, Fulton LA, Chinwalla AT, Pepin KH, Gish WR, Chissoe SL, Wendl MC, Delehaunty KD, Miner TL, Delehaunty A, Kramer JB, Cook LL, Fulton RS, Johnson DL, Minx PJ, Clifton SW, Hawkins T, Branscomb E, Predki P, Richardson P, Wenning S, Slezak T, Doggett N, Cheng JF, Olsen A, Lucas S, Elkin C, Uberbacher E, Frazier M, Gibbs RA, Muzny DM, Scherer SE, Bouck JB, Sodergren EJ, Worley KC, Rives CM, Gorrell JH, Metzker ML, Naylor SL, Kucherlapati RS, Nelson DL, Weinstock GM, Sakaki Y, Fujiyama A, Hattori M, Yada T, Toyoda A, Itoh T, Kawagoe C, Watanabe H, Totoki Y, Taylor T, Weissenbach J, Heilig R, Saurin W, Artiguenave F, Brottier P, Bruls T, Pelletier E, Robert C, Wincker P, Smith DR, Doucette-Stamm L, Rubenfield M, Weinstock K, Lee HM, Dubois J, Rosenthal A, Platzer M, Nyakatura G, Taudien S, Rump A, Yang H, Yu J, Wang J, Huang G, Gu J, Hood L, Rowen L, Madan A, Qin S, Davis RW, Federspiel NA, Abola AP, Proctor MJ, Myers RM, Schmutz J, Dickson M, Grimwood J, Cox DR, Olson MV, Kaul R, Raymond C, Shimizu N, Kawasaki K, Minoshima S, Evans GA, Athanasiou M, Schultz R, Roe BA, Chen F, Pan H, Ramser J, Lehrach H, Reinhardt R, McCombie WR, de la BM, Dedhia N, Blocker H, Hornischer K, Nordsiek G, Agarwala R, Aravind L, Bailey JA, Bateman A, Batzoglou S, Birney E, Bork P, Brown DG, Burge CB, Cerutti L, Chen HC, Church D, Clamp M, Copley RR, Doerks T, Eddy SR, Eichler EE, Furey TS, Galagan J, Gilbert JG, Harmon C, Hayashizaki Y, Haussler D, Hermjakob H, Hokamp K, Jang W, Johnson LS, Jones TA, Kasif S, Kaspryzk A, Kennedy S, Kent WJ, Kitts P, Koonin EV, Korf I, Kulp D, Lancet D, Lowe TM, McLysaght A, Mikkelsen T, Moran JV, Mulder N, Pollara VJ, Ponting CP, Schuler G, Schultz J, Slater G, Smit AF, Stupka E, Szustakowski J, Thierry-Mieg D, Thierry-Mieg J, Wagner L, Wallis J, Wheeler R, Williams A, Wolf YI, Wolfe KH, Yang SP, Yeh RF, Collins F, Guyer MS, Peterson J, Felsenfeld A, Wetterstrand KA, Patrinos A, Morgan MJ, Szustakowki J, de Jong P, Catanese JJ, Osoegawa K, Shizuya H, Choi S. Initial sequencing and analysis of the human genome. Nature 2001;409:860-921. [PubMed: 11237011]

93. Lavigueur A, La Branche H, Kornblihtt AR, Chabot B. A splicing enhancer in the human fibronectin alternate ED1 exon interacts with SR proteins and stimulates U2 snRNP binding. Genes Dev 1993;7:2405-2417. [PubMed: 8253386]

94. Le Guiner C, Plet A, Galiana D, Gesnel MC, Gatto-Konczak F, Breathnach R. Polypyrimidine tractbinding protein represses splicing of a fibroblast growth factor receptor-2 gene alternative exon through exon sequences. J Biol Chem 2001;276:43677-43687. [PubMed: 11557769]

95. Le Hir H, Gatfield D, Izaurralde E, Moore MJ. The exon-exon junction complex provides a binding platform for factors involved in mRNA export and nonsense-mediated mRNA decay. EMBO J 2001;20:4987-4997. [PubMed: 11532962]

96. Lefebvre S, Burglen L, Reboullet S, Clermont O, Burlet P, Viollet L, Benichou B, Cruaud C, Millasseau P, Zeviani M. Identification and characterization of a spinal muscular atrophydetermining gene. Cell 1995;80:155-165. [PubMed: 7813012] 
97. Lefebvre S, Burlet P, Liu Q, Bertrandy S, Clermont O, Munnich A, Dreyfuss G, Melki J. Correlation between severity and SMN protein level in spinal muscular atrophy. Nat Genet 1997;16:265-269. [PubMed: 9207792]

98. Lejeune F, Cavaloc Y, Stevenin J. Alternative splicing of intron 3 of the serine/arginine-rich protein 9G8 gene. Identification of flanking exonic splicing enhancers and involvement of 9G8 as a transacting factor. J Biol Chem 2001;276:7850-7858. [PubMed: 11096110]

99. Lerga A, Hallier M, Delva L, Orvain C, Gallais I, Marie J, Moreau-Gachelin F. Identification of an RNA binding specificity for the potential splicing factor TLS. J Biol Chem 2001;276:6807-6816. [PubMed: 11098054]

100. Lewis BP, Green RE, Brenner SE. Evidence for the widespread coupling of alternative splicing and nonsense-mediated mRNA decay in humans. Proc Natl Acad Sci USA 2003;100:189-192. [PubMed: 12502788]

101. Lewis JD, Izaurralde E, Jarmolowski A, McGuigan C, Mattaj IW. A nuclear cap-binding complex facilitates association of U1 snRNP with the cap-proximal 5' splice site. Genes Dev 1996;10:16831698. [PubMed: 8682298]

102. Li Y, Chen ZY, Wang W, Baker CC, Krug RM. The 3'-end-processing factor CPSF is required for the splicing of single-intron pre-mRNAs in vivo. RNA 2001;7:920-931. [PubMed: 11421366]

103. Liang F, Holt I, Pertea G, Karamycheva S, Salzberg SL, Quackenbush J. Gene index analysis of the human genome estimates approximately 120,000 genes. Nat Genet 2000;25:239-240. [PubMed: 10835646]

104. Lin CL, Li H, Wang Y, Zhu FX, Kudchodkar S, Yuan Y. Kaposi's sarcoma-associated herpesvirus lytic origin (ori-Lyt)-dependent DNA replication: identification of the ori-Lyt and association of K8 bZip protein with the origin. J Virol 2003;77:5578-5588. [PubMed: 12719550]

105. Liu HX, Cartegni L, Zhang MQ, Krainer AR. A mechanism for exon skipping caused by nonsense or missense mutations in BRCA1 and other genes. Nat Genet 2001;27:55-58. [PubMed: 11137998]

106. Liu X, Mayeda A, Tao M, Zheng ZM. Exonic splicing enhancer-dependent selection of the bovine papillomavirus type 1 nucleotide $32253^{\prime}$ splice site can be rescued in a cell lacking splicing factor ASF/SF2 through activation of the phosphatidylinositol 3-kinase/Akt pathway. J Virol 2003;77:2105-2115. [PubMed: 12525645]

107. Lorson CL, Androphy EJ. An exonic enhancer is required for inclusion of an essential exon in the SMA-determining gene SMN. Hum Mol Genet 2000;9:259-265. [PubMed: 10607836]

108. Lorson CL, Hahnen E, Androphy EJ, Wirth B. A single nucleotide in the SMN gene regulates splicing and is responsible for spinal muscular atrophy. Proc Natl Acad Sci USA 1999;96:6307-6311. [PubMed: 10339583]

109. Lykke-Andersen J, Shu MD, Steitz JA. Human Upf proteins target an mRNA for nonsense-mediated decay when bound downstream of a termination codon. Cell 2000;103:1121-1131. [PubMed: 11163187]

110. Lynch KW, Weiss A. A CD45 polymorphism associated with multiple sclerosis disrupts an exonic splicing silencer. J Biol Chem 2001;276:24341-24347. [PubMed: 11306584]

111. Maniatis T, Reed R. An extensive network of coupling among gene expression machines. Nature 2002;416:499-506. [PubMed: 11932736]

112. Maniatis T, Tasic B. Alternative pre-mRNA splicing and proteome expansion in metazoans. Nature 2002;418:236-243. [PubMed: 12110900]

113. Maquat LE, Carmichael GG. Quality control of mRNA function. Cell 2001;104:173-176. [PubMed: 11207359]

114. Marchand V, Mereau A, Jacquenet S, Thomas D, Mougin A, Gattoni R, Stevenin J, Branlant C. A Janus splicing regulatory element modulates HIV-1 tat and rev mRNA production by coordination of hnRNP A1 cooperative binding. J Mol Biol 2002;323:629-652. [PubMed: 12419255]

115. Matter N, Marx M, Weg-Remers S, Ponta H, Herrlich P, Konig H. Heterogeneous ribonucleoprotein A1 is part of an exon-specific splice-silencing complex controlled by oncogenic signaling pathways. J Biol Chem 2000;275:35353-35360. [PubMed: 10958793]

116. Mayeda A, Krainer AR. Regulation of alternative pre-mRNA splicing by hnRNP A1 and splicing factor SF2. Cell 1992;68:365-375. [PubMed: 1531115] 
117. Mayeda A, Screaton GR, Chandler SD, Fu XD, Krainer AR. Substrate specificities of SR proteins in constitutive splicing are determined by their RNA recognition motifs and composite pre-mRNA exonic elements. Mol Cell Biol 1999;19:1853-1863. [PubMed: 10022872]

118. Mazoyer S, Puget N, Perrin-Vidoz L, Lynch HT, Serova-Sinilnikova OM, Lenoir GM. A BRCA1 nonsense mutation causes exon skipping. Am J Hum Genet 1998;62:713-715. [PubMed: 9497265]

119. McCracken S, Fong N, Yankulov K, Ballantyne S, Pan G, Greenblatt J, Patterson SD, Wickens M, Bentley DL. The C-terminal domain of RNA polymerase II couples mRNA processing to transcription. Nature 1997;385:357-361. [PubMed: 9002523]

120. McCracken S, Lambermon M, Blencowe BJ. SRm160 splicing coactivator promotes transcript 3'end cleavage. Mol Cell Biol 2002;22:148-160. [PubMed: 11739730]

121. Misra S, Crosby MA, Mungall CJ, Matthews BB, Campbell KS, Hradecky P, Huang Y, Kaminker JS, Millburn GH, Prochnik SE, Smith CD, Tupy JL, Whitfied EJ, Bayraktaroglu L, Berman BP, Bettencourt BR, Celniker SE, de Grey AD, Drysdale RA, Harris NL, Richter J, Russo S, Schroeder AJ, Shu SQ, Stapleton M, Yamada C, Ashburner M, Gelbart WM, Rubin GM, Lewis SE. Annotation of the Drosophila melanogaster euchromatic genome: a systematic review. Genome Biol 2002;3:RESEARCH0083. [PubMed: 12537572]

122. Moore MJ. Nuclear RNA turnover. Cell 2002;108:431-434. [PubMed: 11909514]

123. Moseley CT, Mullis PE, Prince MA, Phillips JA III. An exon splice enhancer mutation causes autosomal dominant GH deficiency. J Clin Endocrinol Metab 2002;87:847-852. [PubMed: 11836331]

124. Moteki S, Price D. Functional coupling of capping and transcription of mRNA. Mol Cell 2002;10:599-609. [PubMed: 12408827]

125. Muro AF, Caputi M, Pariyarath R, Pagani F, Buratti E, Baralle FE. Regulation of fibronectin EDA exon alternative splicing: possible role of RNA secondary structure for enhancer display. Mol Cell Biol 1999;19:2657-2671. [PubMed: 10082532]

126. Nagel RJ, Lancaster AM, Zahler AM. Specific binding of an exonic splicing enhancer by the premRNA splicing factor SRp55. RNA 1998;4:11-23. [PubMed: 9436904]

127. NCBI. Caenorhabditis elegans genome view. 2003. http://www.ncbi.nlm.nih.gov/mapview/map_search.cgi?chr=celegans.inf

128. O'Mullane L, Eperon IC. The pre-mRNA 5' cap determines whether U6 small nuclear RNA succeeds U1 small nuclear ribonucleoprotein particle at 5' splice sites. Mol Cell Biol 1998;18:7510-7520. [PubMed: 9819436]

129. Okazaki Y, Furuno M, Kasukawa T, Adachi J, Bono H, Kondo S, Nikaido I, Osato N, Saito R, Suzuki H, Yamanaka I, Kiyosawa H, Yagi K, Tomaru Y, Hasegawa Y, Nogami A, Schonbach C, Gojobori T, Baldarelli R, Hill DP, Bult C, Hume DA, Quackenbush J, Schriml LM, Kanapin A, Matsuda H, Batalov S, Beisel KW, Blake JA, Bradt D, Brusic V, Chothia C, Corbani LE, Cousins S, Dalla E, Dragani TA, Fletcher CF, Forrest A, Frazer KS, Gaasterland T, Gariboldi M, Gissi C, Godzik A, Gough J, Grimmond S, Gustincich S, Hirokawa N, Jackson IJ, Jarvis ED, Kanai A, Kawaji H, Kawasawa Y, Kedzierski RM, King BL, Konagaya A, Kurochkin IV, Lee Y, Lenhard B, Lyons PA, Maglott DR, Maltais L, Marchionni L, McKenzie L, Miki H, Nagashima T, Numata K, Okido T, Pavan WJ, Pertea G, Pesole G, Petrovsky N, Pillai R, Pontius JU, Qi D, Ramachandran S, Ravasi T, Reed JC, Reed DJ, Reid J, Ring BZ, Ringwald M, Sandelin A, Schneider C, Semple CA, Setou M, Shimada K, Sultana R, Takenaka Y, Taylor MS, Teasdale RD, Tomita M, Verardo R, Wagner L, Wahlestedt C, Wang Y, Watanabe Y, Wells C, Wilming LG, Wynshaw-Boris A, Yanagisawa M, Yang I, Yang L, Yuan Z, Zavolan M, Zhu Y, Zimmer A, Carninci P, Hayatsu N, Hirozane-Kishikawa T, Konno H, Nakamura M, Sakazume N, Sato K, Shiraki T, Waki K, Kawai J, Aizawa K, Arakawa T, Fukuda S, Hara A, Hashizume W, Imotani K, Ishii Y, Itoh M, Kagawa I, Miyazaki A, Sakai K, Sasaki D, Shibata K, Shinagawa A, Yasunishi A, Yoshino M, Waterston R, Lander ES, Rogers J, Birney E, Hayashizaki Y. Analysis of the mouse transcriptome based on functional annotation of 60,770 full-length cDNAs. Nature 2002;420:563-573. [PubMed: 12466851]

130. Pollard AJ, Krainer AR, Robson SC, Europe-Finner GN. Alternative splicing of the adenylyl cyclase stimulatory G-protein $\mathrm{G}$ alpha(s) is regulated by SF2/ASF and heterogeneous nuclear ribonucleoprotein A1 (hnRNPA1) and involves the use of an unusual TG 3'-splice Site. J Biol Chem 2002;277:15241-15251. [PubMed: 11825891] 
131. Purcell DF, Martin MA. Alternative splicing of human immunodeficiency virus type 1 mRNA modulates viral protein expression, replication, and infectivity. J Virol 1993;67:6365-6378. [PubMed: 8411338]

132. Qiu J, Pintel DJ. The adeno-associated virus type 2 Rep protein regulates RNA processing via interaction with the transcription template. Mol Cell Biol 2002;22:3639-3652. [PubMed: 11997501]

133. Ramchatesingh J, Zahler AM, Neugebauer KM, Roth MB, Cooper TA. A subset of SR proteins activates splicing of the cardiac troponin $\mathrm{T}$ alternative exon by direct interactions with an exonic enhancer. Mol Cell Biol 1995;15:4898-4907. [PubMed: 7651409]

134. Rappsilber J, Ryder U, Lamond AI, Mann M. Large-scale proteomic analysis of the human spliceosome. Genome Res 2002;12:1231-1245. [PubMed: 12176931]

135. Rodrigues JP, Rode M, Gatfield D, Blencowe BJ, Carmo-Fonseca M, Izaurralde E. REF proteins mediate the export of spliced and unspliced mRNAs from the nucleus. Proc Natl Acad Sci USA 2001;98:1030-1035. [PubMed: 11158589]

136. Rooke N, Markovtsov V, Cagavi E, Black DL. Roles for SR proteins and hnRNP A1 in the regulation of c-src exon N1. Mol Cell Biol 2003;23:1874-1884. [PubMed: 12612063]

137. Schaal TD, Maniatis T. Multiple distinct splicing enhancers in the protein-coding sequences of a constitutively spliced pre-mRNA. Mol Cell Biol 1999;19:261-273. [PubMed: 9858550]

138. Screaton GR, Cáceres JF, Mayeda A, Bell MV, Plebanski M, Jackson DG, Bell JI, Krainer AR. Identification and characterization of three members of the human SR family of pre-mRNA splicing factors. EMBO J 1995;14:4336-4349. [PubMed: 7556075]

139. Selvakumar M, Helfman DM. Exonic splicing enhancers contribute to the use of both $3^{\prime}$ and 5' splice site usage of rat beta-tropomyosin pre-mRNA. RNA 1999;5:378-394. [PubMed: 10094307]

140. Seong JY, Han J, Park S, Wuttke W, Jarry H, Kim K. Exonic splicing enhancer-dependent splicing of the gonadotropin-releasing hormone premessenger ribonucleic acid is mediated by tra2alpha, a 40-kilodalton serine/arginine-rich protein. Mol Endocrinol 2002;16:2426-2438. [PubMed: 12403832]

141. Shiga N, Takeshima Y, Sakamoto H, Inoue K, Yokota Y, Yokoyama M, Matsuo M. Disruption of the splicing enhancer sequence within exon 27 of the dystrophin gene by a nonsense mutation induces partial skipping of the exon and is responsible for Becker muscular dystrophy. J Clin Invest 1997;100:2204-2210. [PubMed: 9410897]

142. Si Z, Amendt BA, Stoltzfus CM. Splicing efficiency of human immunodeficiency virus type 1 tat RNA is determined by both a suboptimal 3' splice site and a 10 nucleotide exon splicing silencer element located within tat exon 2. Nucleic Acids Res 1997;25:861-867. [PubMed: 9016638]

143. Si ZH, Rauch D, Stoltzfus CM. The exon splicing silencer in human immunodeficiency virus type 1 Tat exon 3 is bipartite and acts early in spliceosome assembly. Mol Cell Biol 1998;18:5404-5413. [PubMed: 9710624]

144. Smith PJ, Spurrell EL, Coakley J, Hinds CJ, Ross RJ, Krainer AR, Chew SL. An exonic splicing enhancer in human IGF-I pre-mRNA mediates recognition of alternative exon 5 by the serinearginine protein splicing factor-2/alternative splicing factor. Endocrinology 2002;143:146-154. [PubMed: 11751603]

145. Staffa A, Acheson NH, Cochrane A. Novel exonic elements that modulate splicing of the human fibronectin EDA exon. J Biol Chem 1997;272:33394-33401. [PubMed: 9407134]

146. Staffa A, Cochrane A. Identification of positive and negative splicing regulatory elements within the terminal tat-rev exon of human immunodeficiency virus type 1. Mol Cell Biol 1995;15:45974605. [PubMed: 7623851]

147. Steingrimsdottir H, Rowley G, Dorado G, Cole J, Lehmann AR. Mutations which alter splicing in the human hypoxanthine-guanine phosphoribosyltransferase gene. Nucleic Acids Res 1992;20:1201-1208. [PubMed: 1373235]

148. Sterner DA, Carlo T, Berget SM. Architectural limits on split genes. Proc Natl Acad Sci USA 1996;93:15081-15085. [PubMed: 8986767]

149. Stickeler E, Fraser SD, Honig A, Chen AL, Berget SM, Cooper TA. The RNA binding protein YB-1 binds A/C-rich exon enhancers and stimulates splicing of the CD44 alternative exon v4. EMBO J 2001;20:3821-3830. [PubMed: 11447123] 
150. Sun Q, Mayeda A, Hampson RK, Krainer AR, Rottman FM. General splicing factor SF2/ASF promotes alternative splicing by binding to an exonic splicing enhancer. Genes Dev 1993;7:25982608. [PubMed: 8276242]

151. Takagaki Y, Manley JL. RNA recognition by the human polyadenylation factor CstF. Mol Cell Biol 1997;17:3907-3914. [PubMed: 9199325]

152. Tanaka K, Watakabe A, Shimura Y. Polypurine sequences within a downstream exon function as a splicing enhancer. Mol Cell Biol 1994;14:1347-1354. [PubMed: 8289812]

153. Tang S, Zheng ZM. Kaposi's sarcoma-associated herpesvirus K8 exon 3 contains three 5'-splice sites and harbors a K8.1 transcription start site. J Biol Chem 2002;277:14547-14556. [PubMed: 11832484]

154. Tange TO, Kjems J. SF2/ASF binds to a splicing enhancer in the third HIV-1 tat exon and stimulates U2AF binding independently of the RS domain. J Mol Biol 2001;312:649-662. [PubMed: 11575921]

155. Tarn WY, Steitz JA. A novel spliceosome containing U11, U12, and U5 snRNPs excises a minor class (AT-AC) intron in vitro. Cell 1996;84:801-811. [PubMed: 8625417]

156. Tomonaga K, Kobayashi T, Lee BJ, Watanabe M, Kamitani W, Ikuta K. Identification of alternative splicing and negative splicing activity of a nonsegmented negative-strand RNA virus, Borna disease virus. Proc Natl Acad Sci USA 2000;97:12788-12793. [PubMed: 11070091]

157. Tran Q, Coleman TP, Roesser JR. Human transformer 2beta and SRp55 interact with a calcitoninspecific splice enhancer. Biochim Biophys Acta 2003;1625:141-152. [PubMed: 12531473]

158. Tran Q, Roesser JR. SRp55 is a regulator of calcitonin/CGRP alternative RNA splicing. Biochemistry 2003;42:951-957. [PubMed: 12549914]

159. Ullrich B, Ushkaryov YA, Sudhof TC. Cartography of neurexins: more than 1000 isoforms generated by alternative splicing and expressed in distinct subsets of neurons. Neuron 1995;14:497-507. [PubMed: 7695896]

160. Uporova TM, Norton PA, Tuan RS, Bennett VD. Alternative splicing during chondrogenesis: cis and trans factors involved in splicing of fibronectin exon EIIIA. J Cell Biochem 1999;76:341-351. [PubMed: 10618650]

161. Vagner S, Vagner C, Mattaj IW. The carboxyl terminus of vertebrate poly(A) polymerase interacts with U2AF 65 to couple $3^{\prime}$-end processing and splicing. Genes Dev 2000;14:403-413. [PubMed: 10691733]

162. van der SG, Grootscholten PM, van d V, Draaijers TG, Osinga J, Cobben JM, Scheffer H, Buys CH. PCR-based DNA test to confirm clinical diagnosis of autosomal recessive spinal muscular atrophy. Lancet 1995;345:985-986.

163. Venter JC, Adams MD, Myers EW, Li PW, Mural RJ, Sutton GG, Smith HO, Yandell M, Evans CA, Holt RA, Gocayne JD, Amanatides P, Ballew RM, Huson DH, Wortman JR, Zhang Q, Kodira CD, Zheng XH, Chen L, Skupski M, Subramanian G, Thomas PD, Zhang J, Gabor Miklos GL, Nelson C, Broder S, Clark AG, Nadeau J, McKusick VA, Zinder N, Levine AJ, Roberts RJ, Simon M, Slayman C, Hunkapiller M, Bolanos R, Delcher A, Dew I, Fasulo D, Flanigan M, Florea L, Halpern A, Hannenhalli S, Kravitz S, Levy S, Mobarry C, Reinert K, Remington K, Abu-Threideh J, Beasley E, Biddick K, Bonazzi V, Brandon R, Cargill M, Chandramouliswaran I, Charlab R, Chaturvedi K, Deng Z, Di FV, Dunn P, Eilbeck K, Evangelista C, Gabrielian AE, Gan W, Ge W, Gong F, Gu Z, Guan P, Heiman TJ, Higgins ME, Ji RR, Ke Z, Ketchum KA, Lai Z, Lei Y, Li Z, Li J, Liang Y, Lin X, Lu F, Merkulov GV, Milshina N, Moore HM, Naik AK, Narayan VA, Neelam B, Nusskern D, Rusch DB, Salzberg S, Shao W, Shue B, Sun J, Wang Z, Wang A, Wang X, Wang J, Wei M, Wides R, Xiao C, Yan C, Yao A, Ye J, Zhan M, Zhang W, Zhang H, Zhao Q, Zheng L, Zhong F, Zhong W, Zhu S, Zhao S, Gilbert D, Baumhueter S, Spier G, Carter C, Cravchik A, Woodage T, Ali F, An H, Awe A, Baldwin D, Baden H, Barnstead M, Barrow I, Beeson K, Busam D, Carver A, Center A, Cheng ML, Curry L, Danaher S, Davenport L, Desilets R, Dietz S, Dodson K, Doup L, Ferriera S, Garg N, Gluecksmann A, Hart B, Haynes J, Haynes C, Heiner C, Hladun S, Hostin D, Houck J, Howland T, Ibegwam C, Johnson J, Kalush F, Kline L, Koduru S, Love A, Mann F, May D, McCawley S, McIntosh T, McMullen I, Moy M, Moy L, Murphy B, Nelson K, Pfannkoch C, Pratts E, Puri V, Qureshi H, Reardon M, Rodriguez R, Rogers YH, Romblad D, Ruhfel B, Scott R, Sitter C, Smallwood M, Stewart E, Strong R, Suh E, Thomas R, Tint NN, Tse S, Vech C, Wang G, Wetter J, Williams S, Williams M, Windsor S, Winn-Deen E, Wolfe K, Zaveri 
J, Zaveri K, Abril JF, Guigo R, Campbell MJ, Sjolander KV, Karlak B, Kejariwal A, Mi H, Lazareva B, Hatton T, Narechania A, Diemer K, Muruganujan A, Guo N, Sato S, Bafna V, Istrail S, Lippert R, Schwartz R, Walenz B, Yooseph S, Allen D, Basu A, Baxendale J, Blick L, Caminha M, CarnesStine J, Caulk P, Chiang YH, Coyne M, Dahlke C, Mays A, Dombroski M, Donnelly M, Ely D, Esparham S, Fosler C, Gire H, Glanowski S, Glasser K, Glodek A, Gorokhov M, Graham K, Gropman B, Harris M, Heil J, Henderson S, Hoover J, Jennings D, Jordan C, Jordan J, Kasha J, Kagan L, Kraft C, Levitsky A, Lewis M, Liu X, Lopez J, Ma D, Majoros W, McDaniel J, Murphy S, Newman M, Nguyen T, Nguyen N, Nodell M. The sequence of the human genome. Science 2001;291:1304-1351. [PubMed: 11181995]

164. Watakabe A, Tanaka K, Shimura Y. The role of exon sequences in splice site selection. Genes Dev 1993;7:407-418. [PubMed: 8449402]

165. Waterston RH, Lindblad-Toh K, Birney E, Rogers J, Abril JF, Agarwal P, Agarwala R, Ainscough R, Alexandersson M, An P, Antonarakis SE, Attwood J, Baertsch R, Bailey J, Barlow K, Beck S, Berry E, Birren B, Bloom T, Bork P, Botcherby M, Bray N, Brent MR, Brown DG, Brown SD, Bult C, Burton J, Butler J, Campbell RD, Carninci P, Cawley S, Chiaromonte F, Chinwalla AT, Church DM, Clamp M, Clee C, Collins FS, Cook LL, Copley RR, Coulson A, Couronne O, Cuff J, Curwen V, Cutts T, Daly M, David R, Davies J, Delehaunty KD, Deri J, Dermitzakis ET, Dewey C, Dickens NJ, Diekhans M, Dodge S, Dubchak I, Dunn DM, Eddy SR, Elnitski L, Emes RD, Eswara P, Eyras E, Felsenfeld A, Fewell GA, Flicek P, Foley K, Frankel WN, Fulton LA, Fulton RS, Furey TS, Gage D, Gibbs RA, Glusman G, Gnerre S, Goldman N, Goodstadt L, Grafham D, Graves TA, Green ED, Gregory S, Guigo R, Guyer M, Hardison RC, Haussler D, Hayashizaki Y, Hillier LW, Hinrichs A, Hlavina W, Holzer T, Hsu F, Hua A, Hubbard T, Hunt A, Jackson I, Jaffe DB, Johnson LS, Jones M, Jones TA, Joy A, Kamal M, Karlsson EK, Karolchik D, Kasprzyk A, Kawai J, Keibler E, Kells C, Kent WJ, Kirby A, Kolbe DL, Korf I, Kucherlapati RS, Kulbokas EJ, Kulp D, Landers T, Leger JP, Leonard S, Letunic I, LeVine R, Li J, Li M, Lloyd C, Lucas S, Ma B, Maglott DR, Mardis ER, Matthews L, Mauceli E, Mayer JH, McCarthy M, McCombie WR, McLaren S, McLay K, McPherson JD, Meldrim J, Meredith B, Mesirov JP, Miller W, Miner TL, Mongin E, Montgomery KT, Morgan M, Mott R, Mullikin JC, Muzny DM, Nash WE, Nelson JO, Nhan MN, Nicol R, Ning Z, Nusbaum C, O’Connor MJ, Okazaki Y, Oliver K, Overton-Larty E, Pachter L, Parra G, Pepin KH, Peterson J, Pevzner P, Plumb R, Pohl CS, Poliakov A, Ponce TC, Ponting CP, Potter S, Quail M, Reymond A, Roe BA, Roskin KM, Rubin EM, Rust AG, Santos R, Sapojnikov V, Schultz B, Schultz J, Schwartz MS, Schwartz S, Scott C, Seaman S, Searle S, Sharpe T, Sheridan A, Shownkeen R, Sims S, Singer JB, Slater G, Smit A, Smith DR, Spencer B, Stabenau A, Stange-Thomann N, Sugnet C, Suyama M, Tesler G, Thompson J, Torrents D, Trevaskis E, Tromp J, Ucla C, Ureta-Vidal A, Vinson JP, Von Niederhausern AC, Wade CM, Wall M, Weber RJ, Weiss RB, Wendl MC, West AP, Wetterstrand K, Wheeler R, Whelan S, Wierzbowski J, Willey D, Williams S, Wilson RK, Winter E, Worley KC, Wyman D, Yang S, Yang SP, Zdobnov EM, Zody MC, Lander ES. Initial sequencing and comparative analysis of the mouse genome. Nature 2002;420:520-562. [PubMed: 12466850]

166. Wentz MP, Moore BE, Cloyd MW, Berget SM, Donehower LA. A naturally arising mutation of a potential silencer of exon splicing in human immunodeficiency virus type 1 induces dominant aberrant splicing and arrests virus production. J Virol 1997;71:8542-8551. [PubMed: 9343212]

167. Woerfel G, Bindereif A. In vitro selection of exonic splicing enhancer sequences: identification of novel CD44 enhancers. Nucleic Acids Res 2001;29:3204-3211. [PubMed: 11470878]

168. Wu Q, Krainer AR. Purine-rich enhancers function in the AT-AC pre-mRNA splicing pathway and do so independently of intact U1 snRNP. RNA 1998;4:1664-1673. [PubMed: 9848661]

169. Wu Q, Krainer AR. AT-AC pre-mRNA splicing mechanisms and conservation of minor introns in voltage-gated ion channel genes. Mol Cell Biol 1999;19:3225-3236. [PubMed: 10207048]

170. Xu R, Teng J, Cooper TA. The cardiac troponin T alternative exon contains a novel purine-rich positive splicing element. Mol Cell Biol 1993;13:3660-3674. [PubMed: 8388541]

171. Yeakley JM, Morfin J-P, Rosenfeld MG, Fu X-D. A complex of nuclear proteins mediates SR protein binding to a purine-rich splicing enhancer. Proc Natl Acad Sci USA 1996;93:7582-7587. [PubMed: 8755518]

172. Yuryev A, Patturajan M, Litingtung Y, Joshi RV, Gentile C, Gebara M, Corden JL. The C-terminal domain of the largest subunit of RNA polymerase II interacts with a novel set of serine/argininerich proteins. Proc Natl Acad Sci USA 1996;93:6975-6980. [PubMed: 8692929] 
173. Zaphiropoulos PG. Exon skipping and circular RNA formation in transcripts of the human cytochrome P-450 2C18 gene in epidermis and of the rat androgen binding protein gene in testis. Mol Cell Biol 1997;17:2985-2993. [PubMed: 9154796]

174. Zhang MQ. Statistical features of human exons and their flanking regions. Hum Mol Genet 1998;7:919-932. [PubMed: 9536098]

175. Zhang W-J, Wu JY. Functional properties of p54, a novel SR protein active in constitutive and alternative splicing. Mol Cell Biol 1996;16:5400-5408. [PubMed: 8816452]

176. Zheng ZM, He P, Baker CC. Selection of the bovine papillomavirus type 1 nucleotide 3225 3' splice site is regulated through an exonic splicing enhancer and its juxtaposed exonic splicing suppressor. J Virol 1996;70:4691-4699. [PubMed: 8676495]

177. Zheng ZM, He PJ, Baker CC. Structural, functional, and protein binding analyses of bovine papillomavirus type 1 exonic splicing enhancers. J Virol 1997;71:9096-9107. [PubMed: 9371566]

178. Zheng ZM, He PJ, Baker CC. Function of a bovine papillomavirus type 1 exonic splicing suppressor requires a suboptimal upstream 3' splice site. J Virol 1999;73:29-36. [PubMed: 9847303]

179. Zheng ZM, Huynen M, Baker CC. A pyrimidine-rich exonic splicing suppressor binds multiple RNA splicing factors and inhibits spliceosome assembly. Proc Natl Acad Sci USA 1998;95:1408814093. [PubMed: 9826658]

180. Zheng ZM, Quintero J, Reid ES, Gocke C, Baker CC. Optimization of a weak 3' splice site counteracts the function of a bovine papillomavirus type 1 exonic splicing suppressor in vitro and in vivo. J Virol 2000;74:5902-5910. [PubMed: 10846071]

181. Zheng ZM, Reid ES, Baker CC. Utilization of the bovine papillomavirus type 1 late-stage-specific nucleotide 3605 3' splice site is modulated by a novel exonic bipartite regulator but not by an intronic purine-rich element. J Virol 2000;74:10612-10622. [PubMed: 11044105]

182. Zhou Z, Licklider LJ, Gygi SP, Reed R. Comprehensive proteomic analysis of the human spliceosome. Nature 2002;419:182-185. [PubMed: 12226669]

183. Zhou Z, Luo MJ, Straesser K, Katahira J, Hurt E, Reed R. The protein Aly links pre-messengerRNA splicing to nuclear export in metazoans. Nature 2000;407:401-405. [PubMed: 11014198]

184. Zuo P, Maniatis T. The splicing factor U2AF35 mediates critical protein-protein interactions in constitutive and enhancer-dependent splicing. Genes Dev 1996;10:1356-1368. [PubMed: 8647433] 


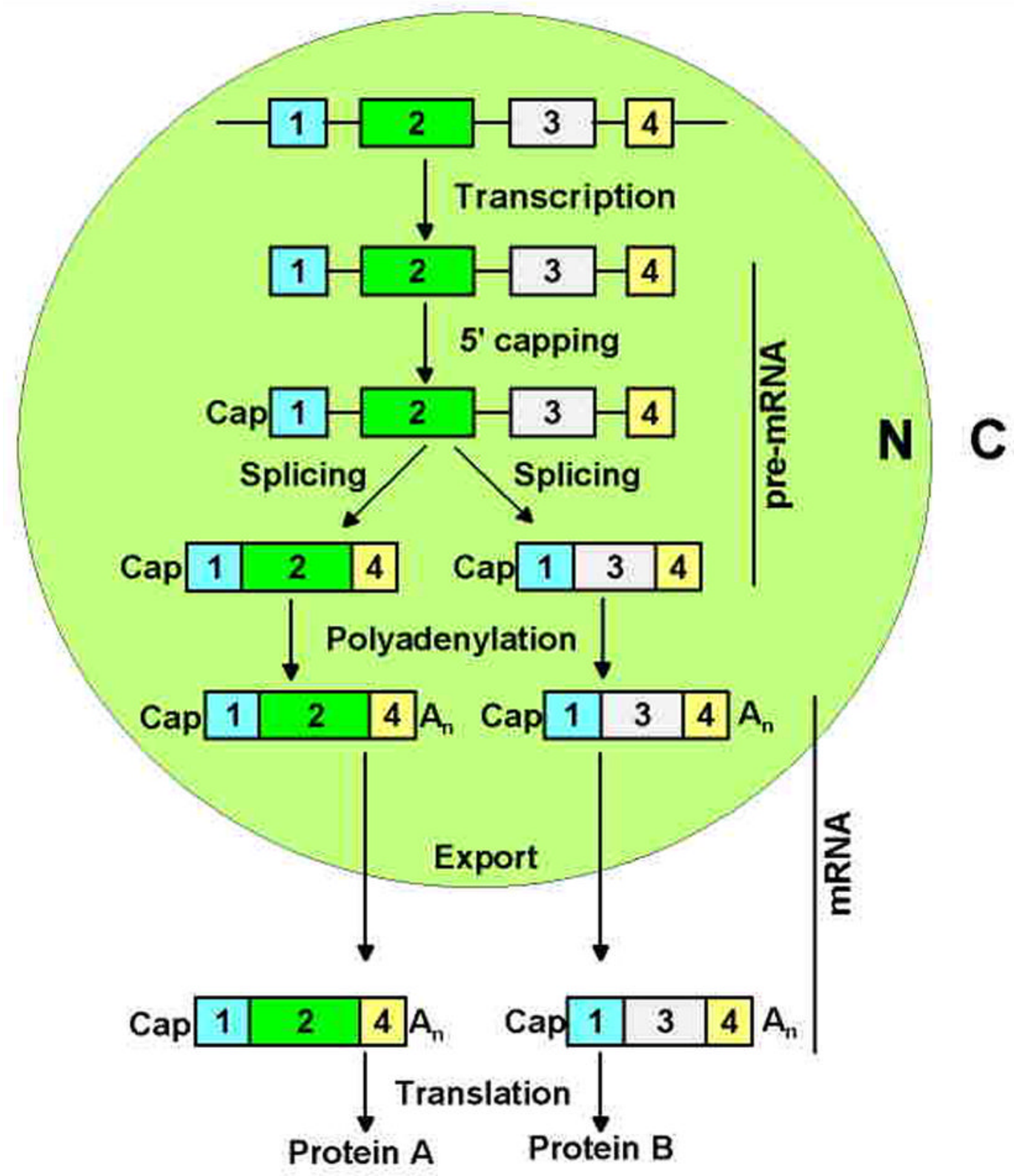

Fig. 1.

Viral and eukaryotic gene expression. Exons (boxes) and introns (lines) are indicated. The diagram illustrates the processing steps that occur before an mRNA is exported from the nucleus for translation. Alternative RNA splicing leads to the production of two isoforms of the message and consequently two different proteins. N, nucleus; $\mathrm{C}$, cytoplasm. 

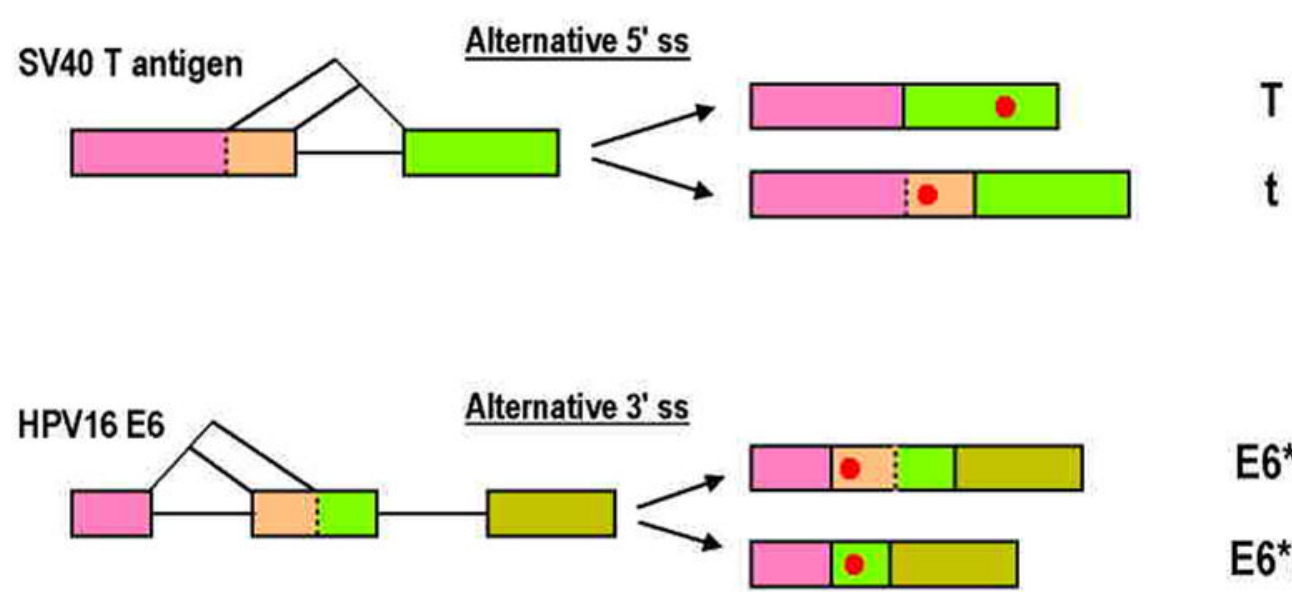

E6*I

E6*II
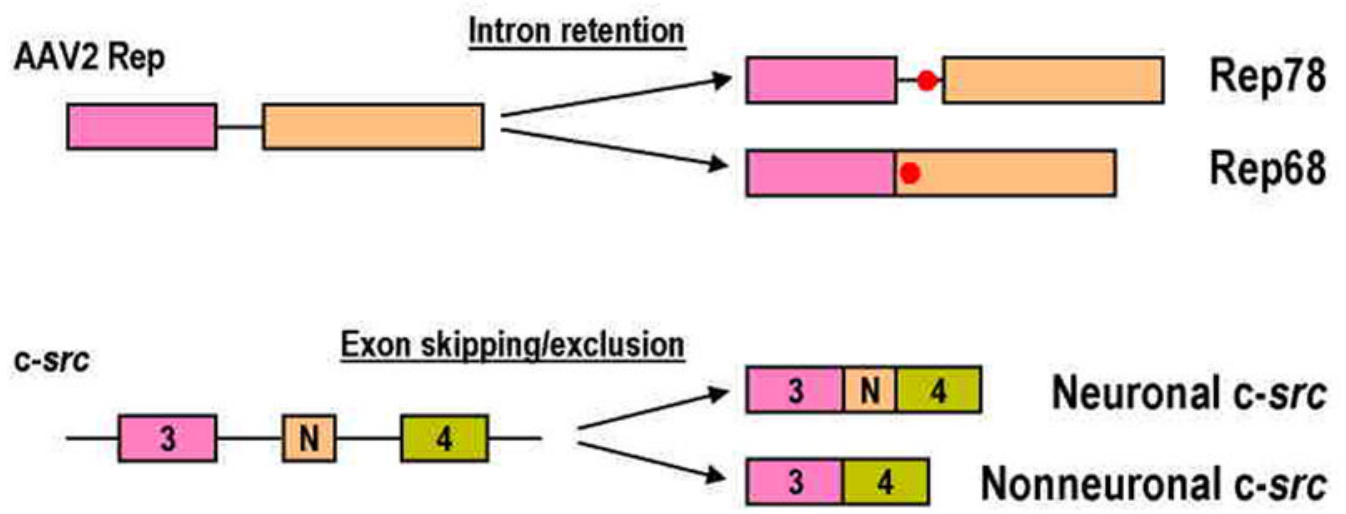

Fig. 2.

Types of viral and mammalian alternative RNA splicing. Examples of splice types occurring naturally in viral and mammalian RNA are shown. Exons (boxes) and introns (lines) are illustrated for each species of RNA. Alternative splice sites are indicated as vertical dashed lines. Red dots show stop codon locations on spliced RNAs. The names of the alternate spliced RNAs are indicated at the right. Drawings are not to scale. SV40 T antigen, simian virus 40 large T antigen RNA; HPV16 E6, human papillomavirus type 16 E6 bicistronic RNA; AAV2 Rep, adeno-associated virus type 2 Rep RNA [132]; mouse c-src RNA [136]. 


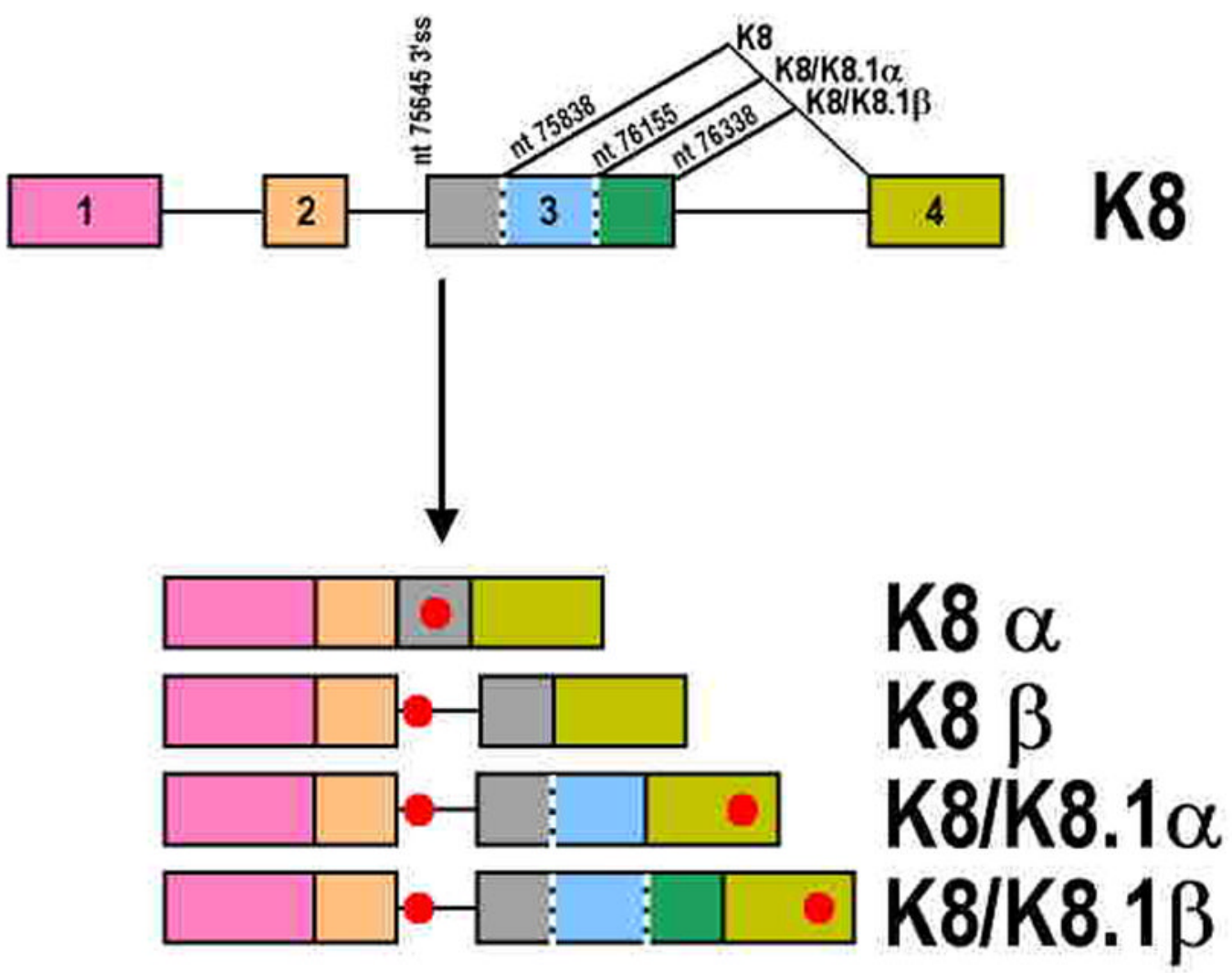

Fig. 3.

Alternative splicing of Kaposi's sarcoma-associated herpesvirus K8 RNA. KSHV K8 exon 3 has three alternative $5^{\prime}$ ss that share a single $3^{\prime}$ ss. See other descriptions in Fig. 2. It has been noted that removal of $\mathrm{K} 8$ intron 2 requires the selection of nt $758385^{\prime}$ ss and exon definition. An incomplete removal of intron 2 leads to production of $\mathrm{K} 8 \beta$. Intron 2 retention is most common in the mRNAs with the use of the other two $5^{\prime}$ ss because selection of either one makes exon 3 larger than $500 \mathrm{nts}$, which restrains exon definition for recognition of upstream 3' ss [153]. Drawings are not to scale. 


\section{A. BPV-1 late RNA splicing}

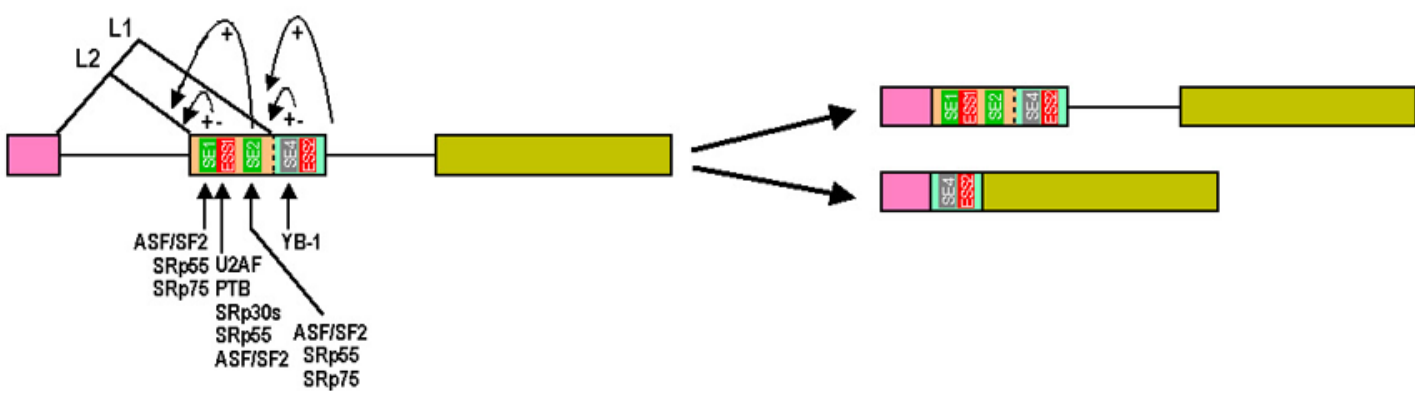

\section{B. Ad2 E1A RNA splicing}
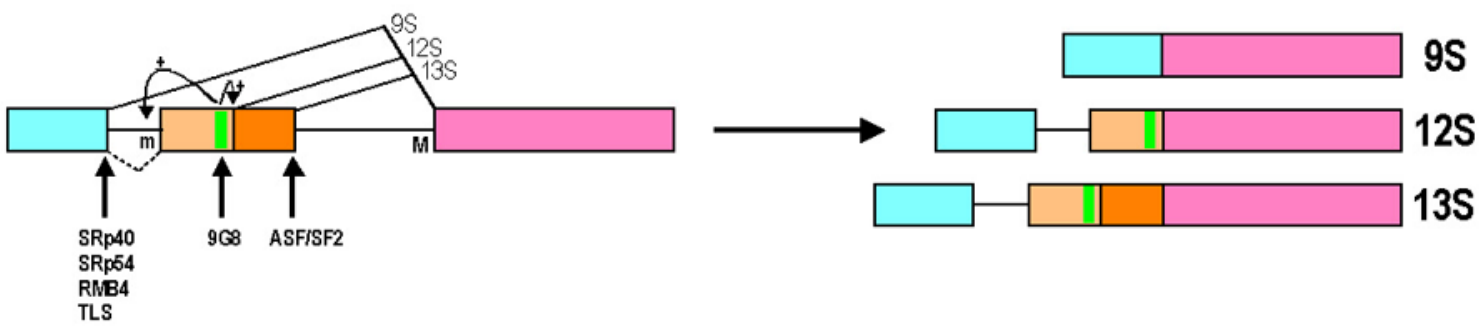

Fig. 4. Regulation of alternative splice site selection by ESE and ESS

A. SR and non-SR proteins (vertical arrows) regulate alternative 3' ss selection on bovine papillomavirus (BPV-1) late pre-mRNA. BPV-1 late pre-mRNA has three exons and two introns, and exon 2 has two alternative $3^{\prime}$ ss. There are five cis-elements, three ESEs [two purine-rich (green boxes) and one AC-rich (grey boxes)] and two ESSs (red boxes), that control individual 3 ' ss switching by interacting with cellular splicing factors, as indicated by the curved arrows. Two purine-rich ESEs (SE1 and SE2) between the two alternative 3' ss synergistically promote the selection of the proximal 3' ss over the suppression by the ESS1 positioned immediately downstream of the SE1. Similarly, an AC-rich ESE (SE4) coordinates with the downstream 5' ss to overcome inhibition by another ESS (ESS2), also positioned immediately downstream of the AC-rich SE4, and to stimulate the distal 3' ss selection. The alternative 3' ss selection leads to production of L2 (proximal 3' ss usage) or L1 (distal 3' ss usage) mRNAs [106].

B. SR and non-SR proteins regulate alternative $5^{\prime}$ ss selection on ad2 E1A pre-mRNA. Ad2 E1A pre-mRNA has three alternative $5^{\prime}$ ss and one major $(\mathrm{M})$ and one minor $(\mathrm{m}) 3^{\prime}$ ss whose modulation occurs during virus infection. Several SR and non-SR proteins have been associated with the regulation of the alternative $5^{\prime}$ ss switch as indicated by vertical arrows. The green box immediate upstream of $12 \mathrm{~S} 5^{\prime}$ ss indicates a purine-rich ESE that functions bidirectionally as a splicing enhancer for selection of both the $12 \mathrm{~S} 5$ 'ss and the upstream, minor $3^{\prime}$ ss [11]. 
A
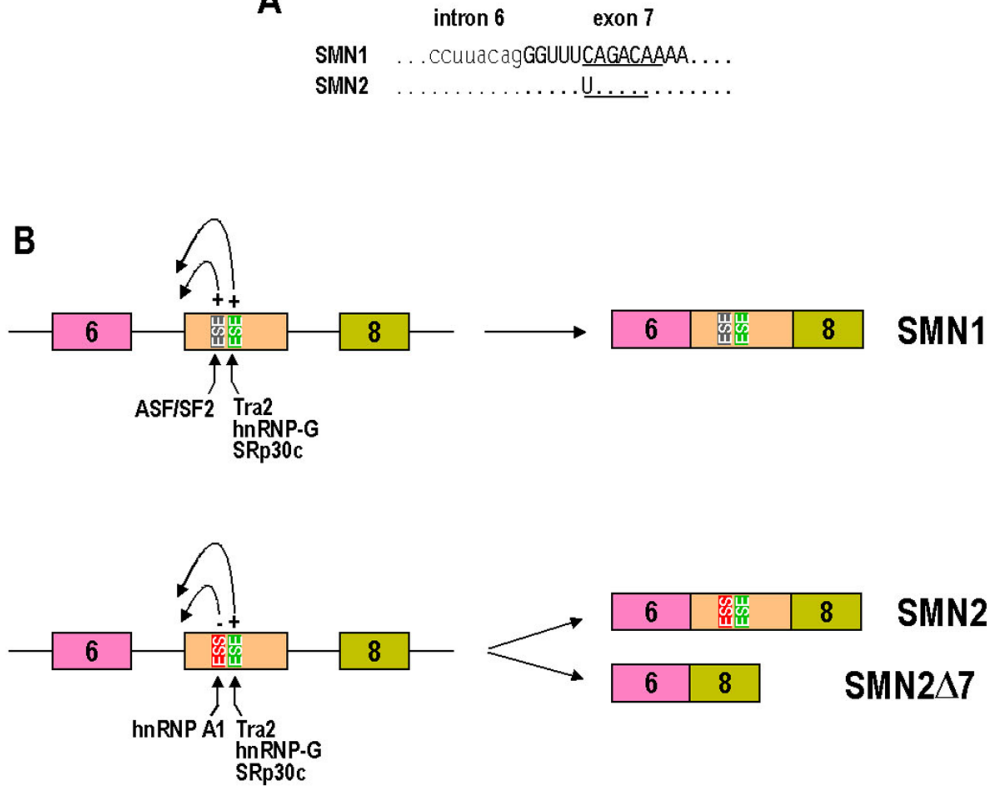

Fig. 5.

Regulation of alternative SMN2 RNA splicing by ESE and ESS. Two identical SMN (survival motor neuron) genes, telomeric SMN1 or SMNt and centromeric SMN2 or SMNc, are located in a 20-kb region on Chromosome 5q13 and each contains 9 exons and encodes a $38 \mathrm{kDa}$ protein with 294 aa expressed at various levels in most tissues with high level in spinal cord [7;30;97]. SMN1 is a disease gene for proximal spinal muscular atrophy (SMA), a relatively common, neurodegenerative disorder in childhood, since $96 \%$ of SMA patients show homozygous absence of SMN1 caused by deletions or point mutations, in particular within exon 6,7 and 8 of SMN1 [65;96;162]. SMN2 determines SMA severity and its expression level correlates with three types (I, severe; II, intermediate; and III, mild) of SMA [12;51] as SMN2 expression is capable of compensating for loss of SMN1. Although DNA and cDNA sequencing of the SMN1 and the SMN2 reveal only 5 nucleotide substitutions that do not alter the protein sequence, a single nt change, $\mathrm{C}$ to $\mathrm{T}$, at codon 280 in exon 7 of the SMN2 (A) has been found to cause the exon to be skipped in majority of SMN2 mRNAs due to this mutation converting an ASF/SF2-binding site [20] into an ESS [85] that counteracts with an existing purine-rich ESE downstream [72;108], resulting in a spliced isoform (SMN2 $\Delta 7)($ B) that encodes a truncated, nonfunctional protein missing the C-terminal 16 residues. Underlines in panel A show an ASF/SF2-binding site (ESE) in SMN1 and an ESS in SMN2 due to a $\mathrm{C}$ to $\mathrm{U}$ mutation at position +6 in exon 7 (capitalized letters). 
Table 1

Genes and RNA splicing in eukaryotes

\begin{tabular}{lccc}
\hline Organism & Estimated no. of genes & No. of genes with alternative splice form \\
$(\%)$ & References \\
\hline Human & & $17,764(66.8)$ & $*$ \\
Mouse & 26,588 & $4750(41)$ & {$[163]$} \\
Worm & 22,011 & $1,891(10)$ & {$[129 ; 165]$} \\
Fly & 20,443 & $2,729(20)$ & {$[127]$} \\
Yeast & 13,676 & $3(0.05)$ & {$[121]$} \\
\hline
\end{tabular}

* Data is based on analysis of 11,677 mouse transcripts [129]. 


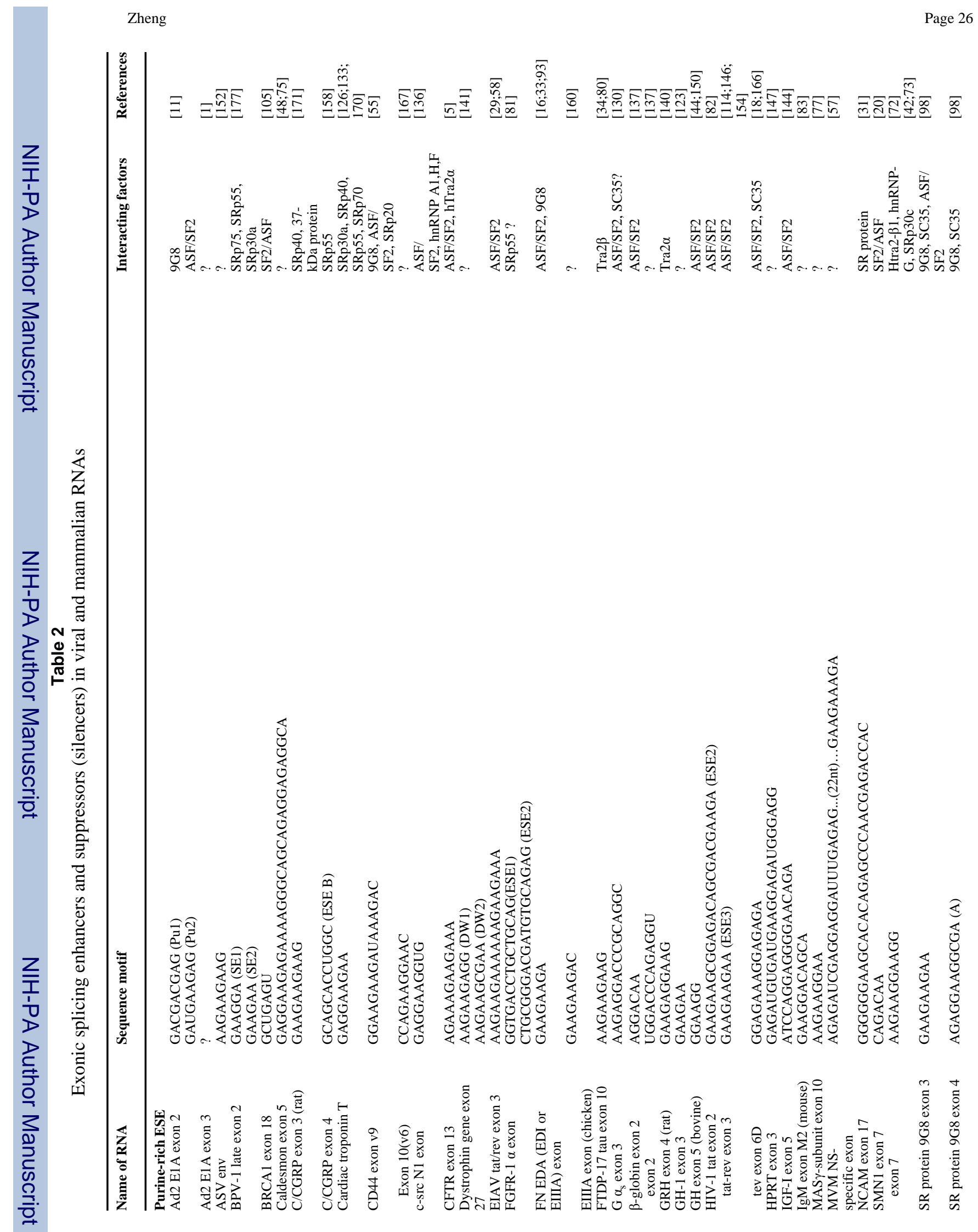

J Biomed Sci. Author manuscript; available in PMC 2008 July 2. 


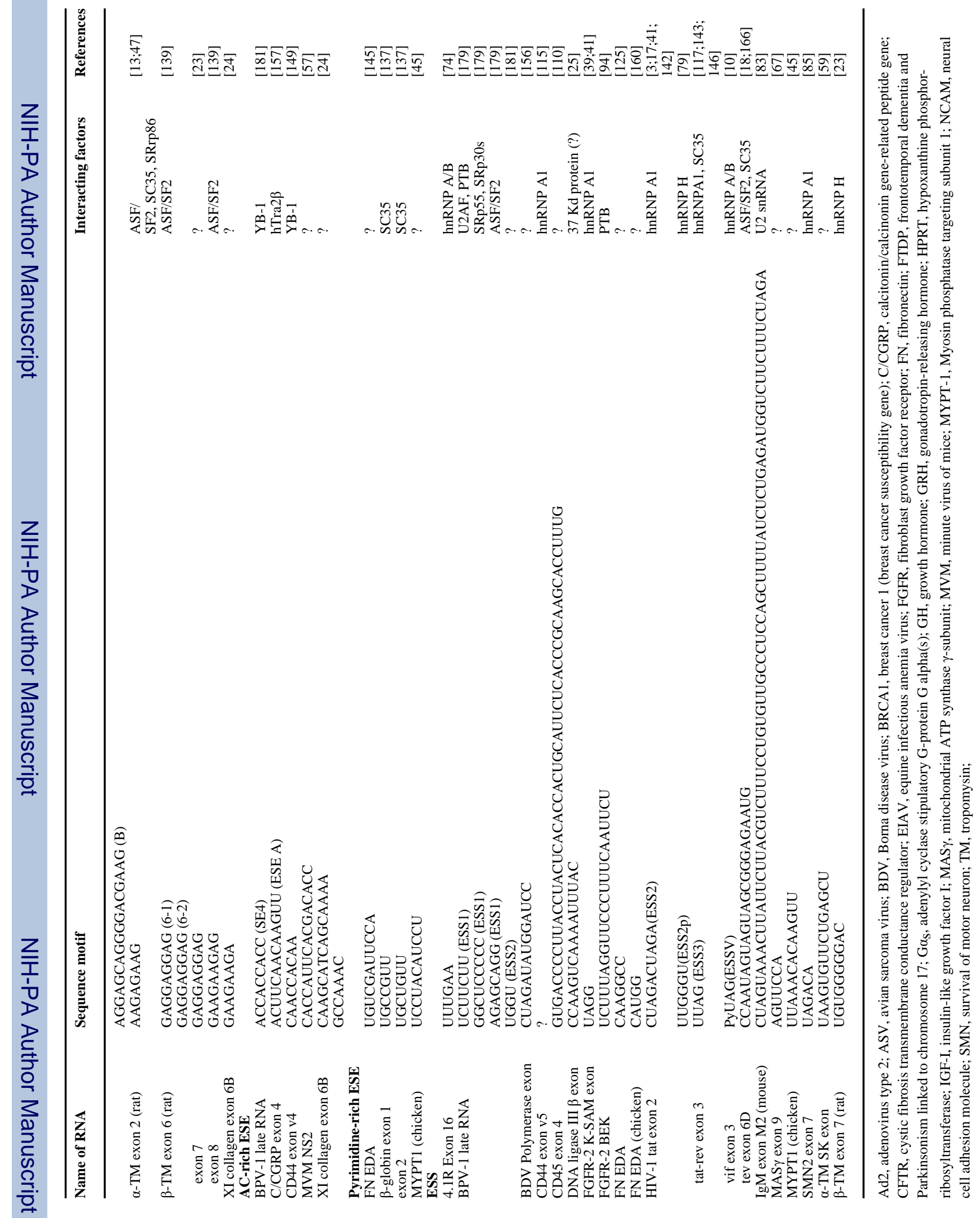

